COMBUSTION AND FUEL CHARACTERIZATION OF COAL-WATER FUELS

VOLUME 2
$\mathrm{DOE} / \mathrm{PC} / 50271--\mathrm{T} 3-\mathrm{VOI} .2$ DE91 000993

SELECTION AND PROCUREMENT OF CANDIDATE COAL-WATER FUELS WITH COMMERCIAL POTENTIAL

PREPARED BY COMBUSTION ENGINEERING, INC.

WINDSOR, CT 06095

PROJECT MANAGER

M. J. HARGROVE

JULY 1989

PREPARED FOR

U.S. DEPARTMENT OF ENERGY

PITTSBURGH ENERGY TECHNOLOGY CENTER UNDER CONTRACT NO. DE-AC 22-82 PC 50271 


\section{ACKNOWLEDGEMENT}

Contributors to this report included $A$. A. Levasseur of Combustion Engineering, Inc.; E. W. Albaugh, B. E. Davis, R. A. Gibson, and J. A. Lowe of Gulf Research and Development Company; and J. P. Dooher and B. J. Gilmartin of Adelphi Center for Energy Studies. 
$\begin{array}{lr}\text { INTRODUCTION } & 1 \\ \text { RESEARCH APPROACH } & 3 \\ \text { DESCRIPTION OF COAL SELECTION } & 13 \\ \text { Procurement of Candidate Coals } & 13 \\ \text { Sampling Procedure } & 13 \\ \text { Preliminary Screening Tests } & 18 \\ \text { Raw Coal Data } & 18 \\ \text { Test Results } & 22\end{array}$

$\begin{array}{ll}\text { SECOND LEVEL SCREENING TESTS } & 27\end{array}$

Float-And-Sink Data $\quad 27$

\begin{tabular}{ll} 
Theoretical Recovery & 27 \\
\hline
\end{tabular}

$\begin{array}{ll}\text { Findings } & 30\end{array}$

$\begin{array}{ll}\text { COAL BENEFICIATION } & 40\end{array}$

Selection of Coal Beneficiator $\quad 40$

Coal Cleaning Methods 42

Expected Clean Coal Properties 43

$\begin{array}{ll}\text { CWF SELECTION } & 48\end{array}$

Fuel Specifications $\quad 48$

Reference CWF Selection $\quad 52$

$\begin{array}{ll}\text { CWF PREPARATION AND SUPPLY } & 63\end{array}$

$\begin{array}{ll}\text { CWF TRANSPORTATION TEST } & 68\end{array}$

$\begin{array}{ll}\text { CONCLUSIONS } & 77\end{array}$ 
I TYPICAL BOILER FUEL QUALITY CHARACTERISTICS

II CWF FEED COAL PROPERTIES (BENEFICIATED) 9

$\begin{array}{lll}\text { III COAL SAMPLE ACQUISITION DATA } & 14\end{array}$

IV ANALYSES SCHEDULE

(FIRST LEVEL WASHABILITY)

$\checkmark \quad$ RESULTS OF RAW COAL ANALYSIS (RUN-OF-MINE)

VI PROXIMATE AND SULFUR FORMS ANALYSES OF 1.3 FLOAT FRACTION

VII ASH AND SULFUR ANALYSES -1.3 SINK FRACTION 21

VIII ASH ANALYSIS- -1.3 FLOAT FRACTION 23

IX ASH COMPOSITION ANALYSIS- -1.3 FLOAT FRACTION 24

$X \quad$ ESTIMATED 2\% ASH P.ECOVERY 26

XI SECOND LEVEL WASHABILITY ANALYSES 28

$\begin{array}{lll}\text { XII THEORETICAL 7\% ASH RECOVERY } & 29\end{array}$

$\begin{array}{ll}\text { XIII THEORETICAL 2\% ASH RECOVERY } & 39\end{array}$

XIV LIST OF CANDIDATE BENEFICIATORS 41

XV ESTIMATED 2\% ASH RECOVERY 47

XVI GENERALIIZED CWF CANDIDATE COAL RATINGS 49

$\begin{array}{lll}\text { XVII PROPOSED SPECIFICATIONS FOR CWFS } & 50\end{array}$

XVIII CHARACTERIZATION TESTS FOR CWFS 53

XIX PROCEDURES FOR CHARACTERIZATION OF CWF

XX ANALYSIS OF LOWER KITTANNING CWF 58

XXI PROPERTIES OF SMALL BATCHES OF SPLASH DAM CWF 60

XXII PROPERTIES OF LARGE BATCHES OF SPLASH DAM CWF 61 


\section{LIST OF TABLES (Continued)}

$\underline{\text { Table }}$

Page

XXIII STABILITY SETTLING COLUMN DATA 62

XXIV VIBRATION MEASURED IN FIELD

XXV TRANSPORTATION SETTLING TEST - TRIP 2

XXVI GENERALIZED CANDIDATE COAL RATINGS 78 


\section{LIST OF FIGURES}

Figure

$\underline{\text { Page }}$

1 OVERVIEW OF PROJECT ACTIVITIES

2 CWF HEATING VALUES

3 SIZE-WEIGHT RELATIONSHIP FOR COAL SAMPLES

WASHABILITY CURVES FOR CEDAR GROVE COAL

WASHABILITY CURVES FOR LOWER ELKHORN COAL

WASHABILITY CURVES FOR BLACK CREEK COAL

WASHABILITY CURVES FOR SPLASH DAM COAL

WASHABILITY CURVES FOR LOWER KITTANNING COAL

WASHABILITY CURVES FOR WESTERN KENTUCKY \# 11 CCAL

WASHABILITY CURVES FOR PITTSBURGH \#8 (OH) COAL

11 WASHABILITY CURVES FOR UPPER FREEPORT COAL

12 HEAVY MEDIUM CYCLON E CIRCUIT

ISU 8-INCH CYCLONE TISTTRIBUTION CURVE

14 HISTORY OF SPLASH DAM CWF PROCUREMENT

15. HISTORY OF CEDAR GROVE CWF PROCUREMENT

16 HISTORY OF UPPER FREEPORT CWF PROCUREMENT

17 TRANSPORTATION MONITORING SYSTEM 


\section{INTRODUCTION}

Coal-water fuel mixtures (CWFs) which typically contain $70 \%$ pulverized coal, $30 \%$ water, and less than $1 \%$ chemical additives, have the potential of replacing fuel oil in commercial furnaces. Use of these coal-based fuels could lessen U.S. dependency on imported $0 i 1$ and reduce power generating costs.

Commercial development of CWF has been impeded by technical and economic uncertainties. The key technical question concerns the impact an ash-bearing CWF would have on furnaces originally designed for ash-free or very low ash fuels. Economic feasibility - in terms of boiler derating, equipment modification, and retrofit costs - will largely depend upon the degree to which CWF affects boiler performance. Resolution of these unanswered technical and economic questions is an essential prerequisite to the commercial development of CWFs as alternatives to fuel oil. In response to this need, the Pittsburgh Energy Technology Center (PETC) of the Department of Energy initiated a comprehensive effort in 1982 to develop the necessary performance and cost data and to assess the commercial viability of CWFs as applied to representative utility and industrial units.

Combustion Engineering, Inc. (C-E) was contracted to conduct the project. The effort comprised six tasks beginning with coal resource evaluation and culminating in the assessment of the technical and economic consequences of switching representative commercial units from oil to state-of-the-art CWF firing. Extensive bench; pilot and commercial-scale tests were performed by C-E to develop necessary CWF combustion and fireside performance data for the subsequent boiler performance analyses and retrofit cost estimates. Gulf Research and Development Company, Energy International, Inc., and the Adelphi Center for Energy Studies provided essential sub-contract support in various aspects of source coal characterization and selection, coal preparation and procurement, and the determination of detailed fuel properties. CWFs were prepared for this project by Advanced Fuels Technology, Atlantic Research, Coaliquid, Ergon, and OXCE Fuel Company. 
This report (Volume 2) provides a review of the fucl selection and procurement activities. Other results of the project are provided in the following volumes:

\begin{tabular}{|c|c|}
\hline $\begin{aligned} \text { Volume } 1 \text { - Tasks } 1 \\
\text { through } 6\end{aligned}$ & Final Summary Report \\
\hline Volume 3 - Task 2 & $\begin{array}{l}\text { Bench-Scale Characterization of Chemical, } \\
\text { Physical and Combustion Properties of Coal-Water } \\
\text { Fuels }\end{array}$ \\
\hline Volume 4 - Task 4 & Commercial-Scale Atomizer and Burner Evaluation \\
\hline Volume 5 - Task 5 & $\begin{array}{l}\text { Pilot-Scale Ash Deposition and Performance } \\
\text { Testing of Coal-Water Fuels }\end{array}$ \\
\hline Volume 6 - Task 6 & $\begin{array}{l}\text { Commercial Application and Economics of } \\
\text { Coal-Water Fuels }\end{array}$ \\
\hline
\end{tabular}




\section{RESEARCH APPROACH}

The project was organized to respond directly to the probable needs of CWF users. Five major tasks were defined to establish the technical data base necessary for boller performance analyses. Established boller performance models then utilized these data, in a sixth task, to establish specific load-limiting factors and to determine consequent equipment modification and ritrofit costs. Finaliy, economic feasibilities in terms of payback periods were estimated for several boiler types and CWF properties based upon fuel price differentials.

To ensure commercial relevance, criteria consistent with the expected market were defined for each task. Coal resources, beneficiation processes, and coal-water fuel producers were evaluated and selected on the basis of availability, suitability (as measured by test criteria), and other commercial considerations. Engineering evaluations of atomization, combustion, and fireside performance of the selected CWFs were based upon test equipment and procedures used regularly for coal-fired and 0i1-fired boiler performance tests. Overall program logic is reflected in the task responsibilities illustrated in Figure 1.

\section{Selection of Test Fuels}

The fuels tested were CWFs having formulations representative of those that are expected to become available commercially. The selected CWFs were made from five coal sources, two levels of beneficiation, and five commercial suppliers.

Based upon published data; twenty coals from the Eastern Untied States were initially selected and subjected to first level screening tests. Key criteria included commercial significance, beneficiation potential, ash content and quality, sulfur content, volatile matter content, and char reactivity. Since coal beneficiation is expected to play a major role in the commercial use of CWFs, the selection process considered the anticipated 


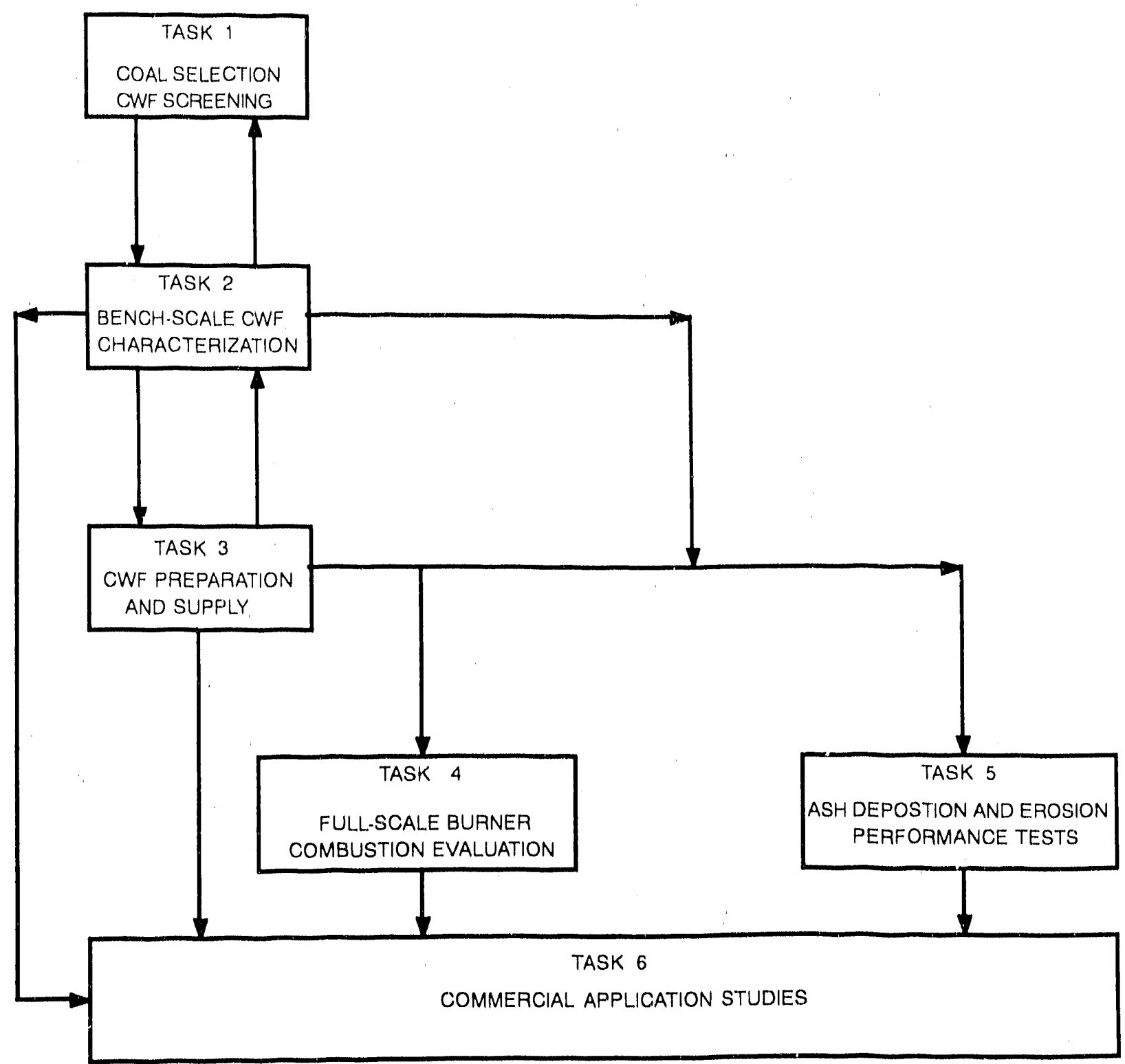

FIGURE 1 OVERVIEW OF PROJECT ACTIVITIES 
characteristics of the coal after beneficiation. As part of these screening tests, gravity separation (14 mesh at 1.3 specific gravity) and subsequent analysis of the two density fractions plus the raw coal were performed.

Based upon results of the first level screening tests, eight coals were selected for second level screening tests. These tests consisted of detailed "washability" analyses and detailed fuel analyses.

The results of the second level screening tests were used to select source coals for beneficiation and for preparation of CWFs for large-scale testing. Cedar Grove, Splash Dam, and Upper Freeport. CWFs were tested at bench scale, pilot scale and full scale. A Lower Kittanning coal and an Alma seam coal were used to make CWFs for bench-scale and pilot-scale tests. These selected coals provided a range in fuel characteristics including varying volatile matter content and ash quality.

\section{Program Objectives}

The purpose of this project is to evaluate coal-water fuels (CWFs) as replacement fuels in oil-burning facilities. This involves not only a detailed investigation of the physical and combustion properties of the CWFs, but also an evaluation of the chemical, physical, and combustion properties of the source coal and their impact on CWF properties.

The initial phase of this research, therefore, involved an evaluation of the chemica1, physical, and combustion properties of the source coals. Twenty coals were selected for the initial screening washability studies for the CiNF program. After completion of the preliminary studies and an evaluation of test data, eight coals were selected for further detailed washability studies. These detailed studies were completed and the washability data evaluated.

Feed coals for the formulation of test CWFs were recommended. Each coal was to be beneficiated to two levels to evaluate the influence of ash on manufacturing and combustion of the CWFs. The levels of beneficiation were defined as follows: 
1. $7 \%$ ash on a dry basis, $\pm 10 \%$

2. $2 \%$ ash on a dry basis, $\pm 20 \%$

\section{Candidate Coal Selection}

Table I is an excerpt from an American Electric Power report 1isting typical boller fuel-quality characteristics for steam coal. In general, these parameters were used as "first-pass" guidelines for selecting sources of coal for CWFs. It should also be mentioned that only coals from major bituminous resources were considered for selection. The limits presented in Table I reflect the environmental emissions standards, combustion characteristics, and boiler fouling potential for coals normally associated with steam use. They may not, however, adequately reflect the desired combustion characteristics for coals to be used as CWF fuels.

The moisture added to the coal during CWF preparation effectively reduces the heating value of the fuel. This relationship between calorific value of the coal and the resulting calorific value of the CWF is illustrated graphically in Figure 2. Fuel 011 typically has a calorific value of 1,9,000 Btu/lb with a specific gravity of 0.9 . Obviously, this heating value cannot be matched with a CWF. However, a favorable comparison can be made with a minimum calorific value for steam coal given as $11,160 \mathrm{Btu} / \mathrm{lb}$. Coals with heating values greater than 13,500 Btu/1b are preferred, when considering CWFs loaded up to $70 \%$ solids.

In addition to having adequate heating values, the candidate CWF coals mus $t$ have good combustion properties. The ratio of fixed carbon to volatile matter, or fuel ratio, is a good indicator of combustibility. For adequate combustion performance, the fuel ratio of the coal should be less than 2.2.

The selection criteria used in identifying the twenty candidate coals for this study are summarized in Table II. These Iimits provide guidelines reflective of the environmental emissions standards, combustion characteristics, and boiler fouling potential for coals to be used as CWFs. 


\section{TYPICAL BOILER FUEL QUALITY CHARACTERISTICS}

\section{Characteristic}

1. Total Moisture

2. Proximate Analysis Fuel Ratio FC/VM

3. Ash

4. Total Sulfur (Air Dry Basis)

5. Calorific Value (Air Dry Basis)

6. Nitrogen (Dry Basis) U1timate Analysis

7. Grindability (Hardgrove Index)

8. Size Consistency

9. Ash Deformation Temperature

10. Slagging Potential
Desirable Value for Electric Utility

$10 \% \operatorname{Max}$.

$2.2 \max$.

$15 \%$

$1.0 \% \operatorname{Max}$.

11,160 Btu/1b Min.

1.7 Max., less than

1.6 Desirable

$45 \mathrm{Min}$.

$40 M M \times 0100 \%$

2 MM $\times 030 \%$

$1,150^{\circ} \mathrm{C} \mathrm{Min.}$

Low 


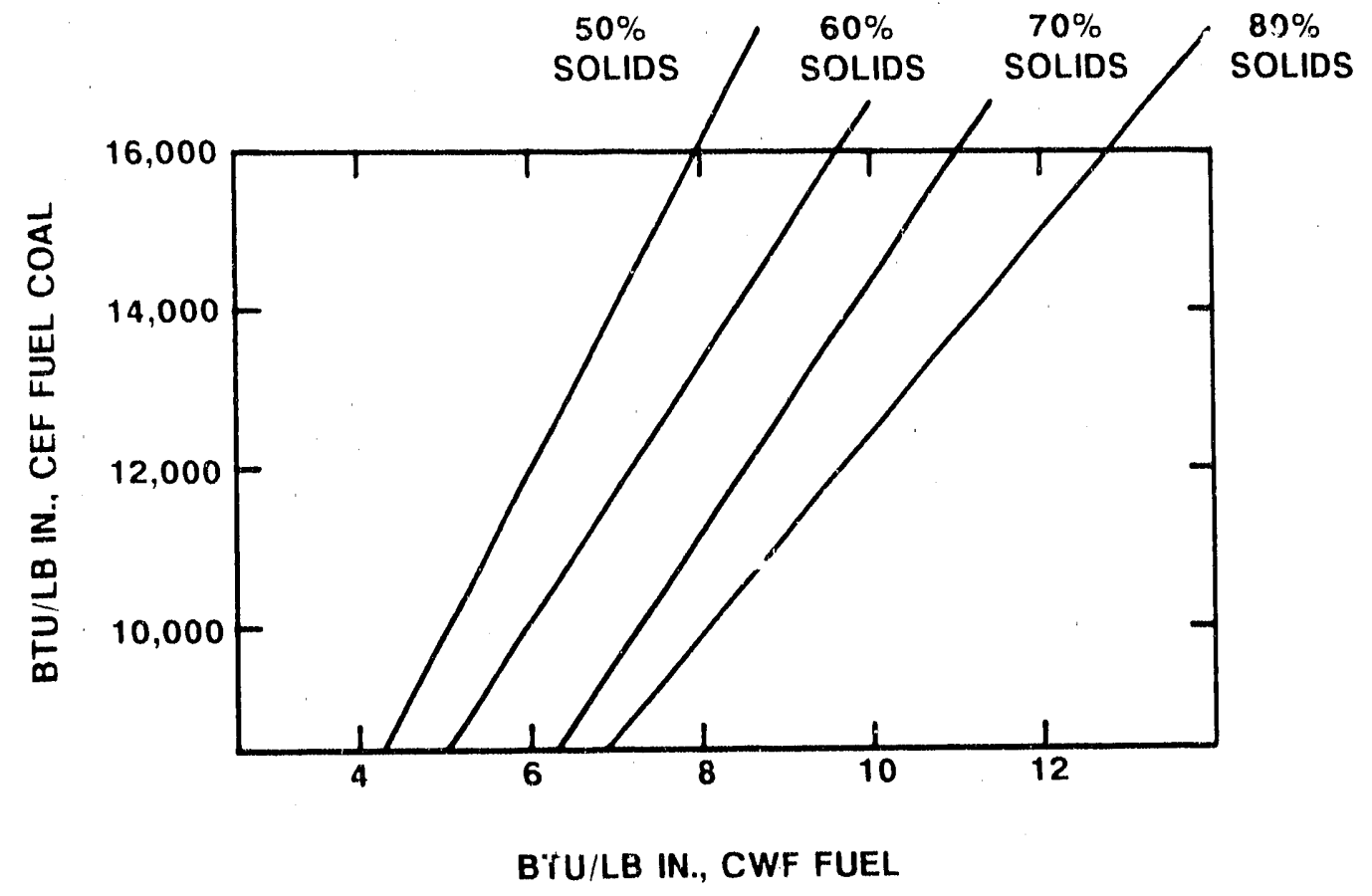

FIGURE 2 CWF FUEL HEATING VALIUE 
Sulfur

Ash

Volatile Matter

Moisture

Heating Value

Fuel Ratio (FC/VM)

TGA

Flammability Index

Ash Properties

Softening Temperature

Fluid Temp,

Free Quartz (\% of ash)

Sodium Content ( $\%$ of ash)

Slurryability
$<1.2 \mathrm{Ib} \mathrm{SO}_{2} / 10^{6} \mathrm{Btu}$

$(0.8 \%$ sulfur a $13,300 \mathrm{Btu} / 1 \mathrm{~b})$

$<2 \%$

$>29 \%$

$<7 \%$

$>13,500 \mathrm{Btu} / \mathrm{lb}$

$<2.2$

$<7$ minutes for $99 \%$ burnout

$<1000^{\circ} \mathrm{F}$

$>2300^{\circ} \mathrm{F}$ (red, atm)

$>2500^{\circ} \mathrm{F}$ (red. atm)

25\% Maximum

$2 \%$ Maximum

Vendor approval 
The coal properties listed in Table II were not used as absolute specifications for which to eliminate coals. Rather, the degree of conformity of coals to the Table II propertiss were weighed together with other selection guidelines.

Selection Criteria: Eight Coals for Detailed Studies

The criteria used for selecting the eight coals for detailed washability studies are relatively straightforward. They are discussed in descending order of importance as follows:

1. Ease of separation. This is related to the specific gravity of separation required to produce $2 \%$ ash coal. The most significant indicators are the ash contents and the recovery. If the ash content of the 1.3 specific gravity fraction is less than $2.4 \%$ and the recovery high ( $50 \%$ or greater), it is suspected that the Level 4 beneficiation can be accomplished.

2. Estimated recovery of the $2 \%$ ash fraction. Generally, the larger this value, the greater the yields and the easier the separation. However, differences in ash levels for the same gravity fractions can significantly alter the ease of separation among coals of similar estimated recoveries.

3. Heating value (moisture and ash free). It can generally be considered, in the case of CWFs, that a higher heating value coal should produce a higher value product for the same level of processing. Of course, in the final analysis, the CWF user/supplier must weigh the economic benefits of acquiring higher quality coals versus sacrificing CWF quality for lower coal costs.

The criteria listed above were considered to be the most important factors for selection of the eight coals. All other criteria were considered to be of lesser importance and were applied in the final selection of the five coals for preparation into slurries. 
Selection Criteria: Four CWF Feed Coals

The primary objective of the coal screening and selection phase of this research was to identify four coals that were viable candidates for use in CWFs and that can be successfully beneficiated to $7 \%$ and $2 \%$ ash. It is expressed or implied in this statement that a number of coal characteristics or properties be concurrently evaluated in order to identify "viable candidates." These include: washability characteristics, combustion properties and ash fouling potential, and characteristics effecting CWF manufacturing. Each of these is briefly discussed in the following paragraphs.

From a beneficiation standpoint, the coals must yield reasonable quantities of two percent ash product, preferably at coarser gradations (plus 28 mesh). Generally, coals which require grinding to a fine particle size for ash liberation lend themselves to more expensive, less efficient, and lower capacity physical cleaning methods. Based on the results of the detailed washability studies and proposals submitied by six candidate beneficiators, a $3 / 8$ inch by 28 mesh size range was selected as being the most workable and cost effective choice for this project. Coals which yield the highest recoveries of two percent product for this size range were considered CWF candidate coals.

Another parameter given consideration in the selection process was the coal's combustion characteristics. As previously mentioned, the fixed carbon-to-volatile matter ratio provides a general indication of a coal's combustion character. Since this ratio, along with other standard ASTM analyses, provides only an indirect indication of combustion properties, two in-house Combustion Engineering (C-E) tests (Flammability and TGA) were conducted which provide more direct measurements. The relative values obtained from these tests were compared with those from C-E's data base to indicate a coal's flame stability, turndown characteristics, and fuel reactivity. 
A third criterion used in selecting the CWF candidate coals was the slurry vendors' analysis of the coals from a manufacturing standpoint. At the request of one CWF manufacturer seiected for this project, the following tests were conducted on each of the coals considered prime CWF candidates:
1. Ultimaite Analysis,
2. Proximate Analysis,
3. Hardgrove Grindability,
4. Equilibrium Moisture, and
6. Ash Composition.

The exact nature of the analysis of these data is not known and is considered, by the vendor, to be proprietary. In addition, test CWF batches were prepared and evaluated by the vendors in order to further define the effect of the feed coal on CWF manufacturing.

It is readily apparent from the previous discussion that a purely analytical approach to selecting the candidate coals for this program could not be used. In some cases it is necessary to resort to more subjective and/or empirical methods in order to identify coals that are "viable candidates" for use in CWFs. Each of these criteria will be discussed in more detail later in this report with reference to particular coals. 


\section{DESCRIPTION OF COAL SELECTION}

\section{Procurement of Candidate Coals}

Run-of-mine (ROM) samples were obtained from each of the 20 coal seams 1isted in Table III. Initially, each mine was contacted to confirm their commitment to participate in the project and to establish a date for sample collection. None of the mines visited were operating at full capacity and, in some cases, special arrangements were necessary to obtain the small sample required for this project. Excellent cooperation was afforded by each of the participating companies.

\section{Sampling Procedure}

The procedure for securing samples of each of the 20 candidate coals involves selecting a sample quantity which will satisfy two basic requirements: (1) an adequate amount is obtained, such that representative sample is assured; and (2) a sufficient amount of coal is obtained to allow both the screening and detalled washability studies to be conducted without resampling.

Guidelines for selecting representative sample amounts were based on the maximum nominal particle size of the coal. This relationship between particle size and minimum sample weight is lllustrated in Figure 3. A maximum nominal particle size of six inches was anticipated for mines employing surface mining or conventional underground mining techniques. Utilizing the curves from Figure 3 as a guide, ar eight-ton sample amount was considered adequate and was used as the requirement for all samples. Although this amount far exceeds that which was required to conduct the washablity testing, it was necessary in order to ensure that a representative sample was obtained. 


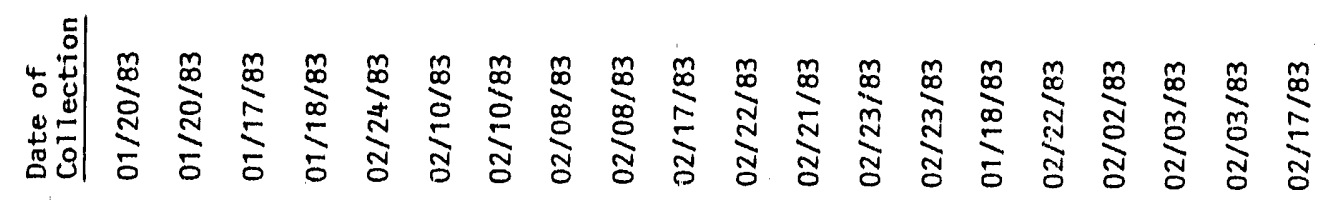
$b_{y} \ldots \ldots \ldots \ldots \ldots \ldots$ 镱

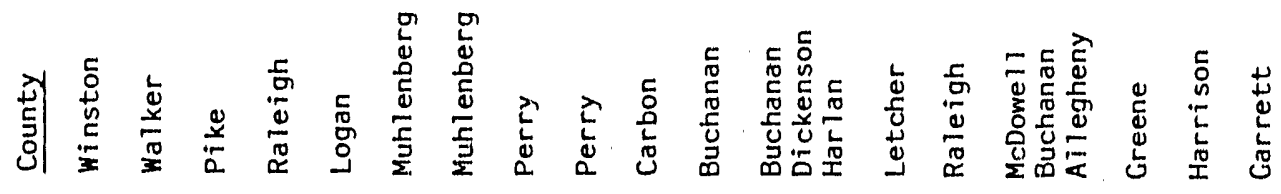

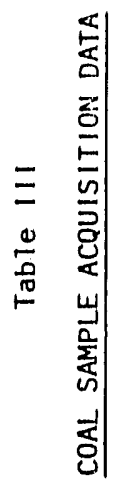

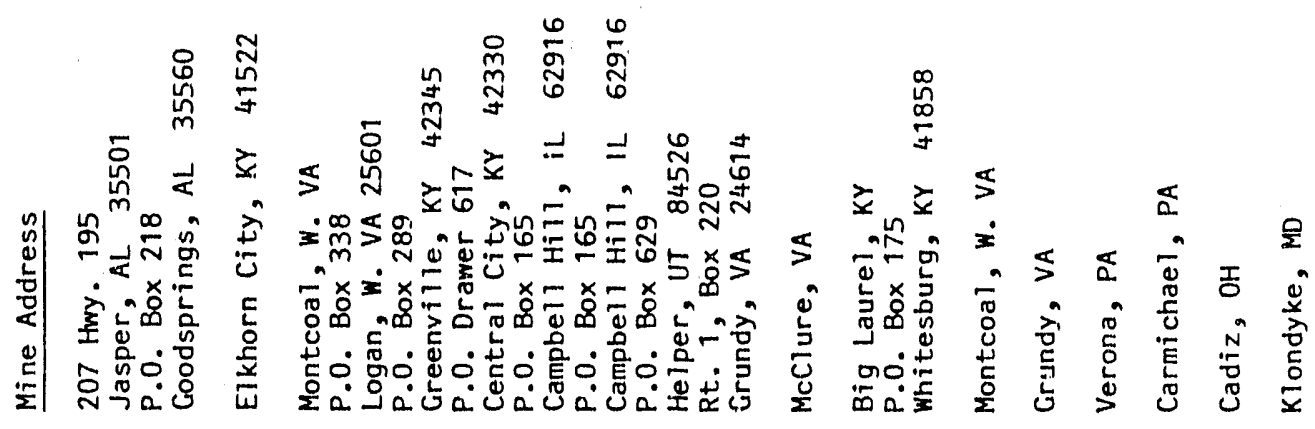

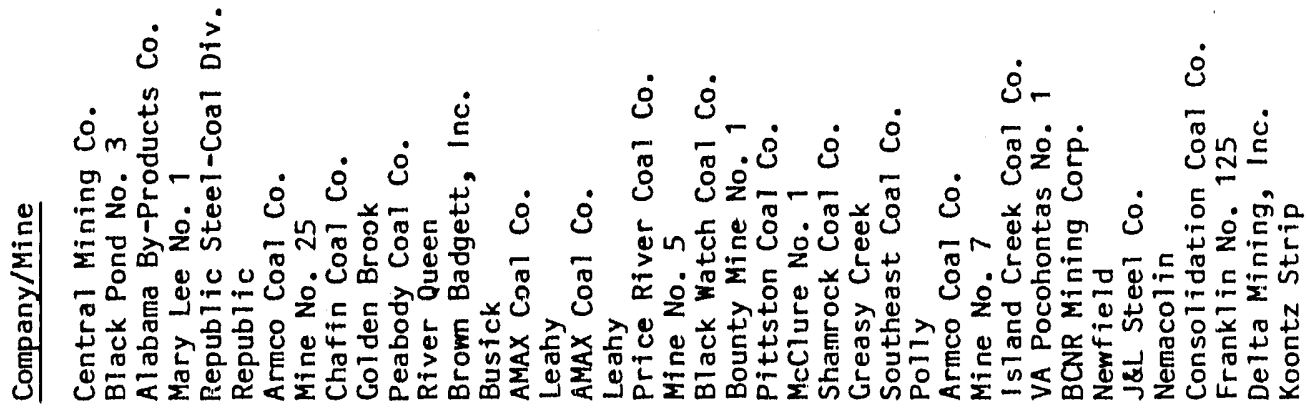

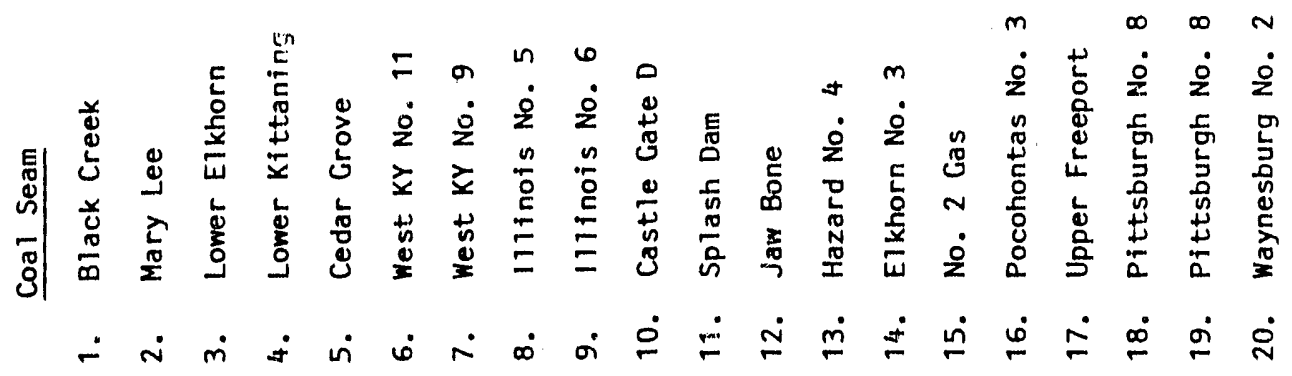




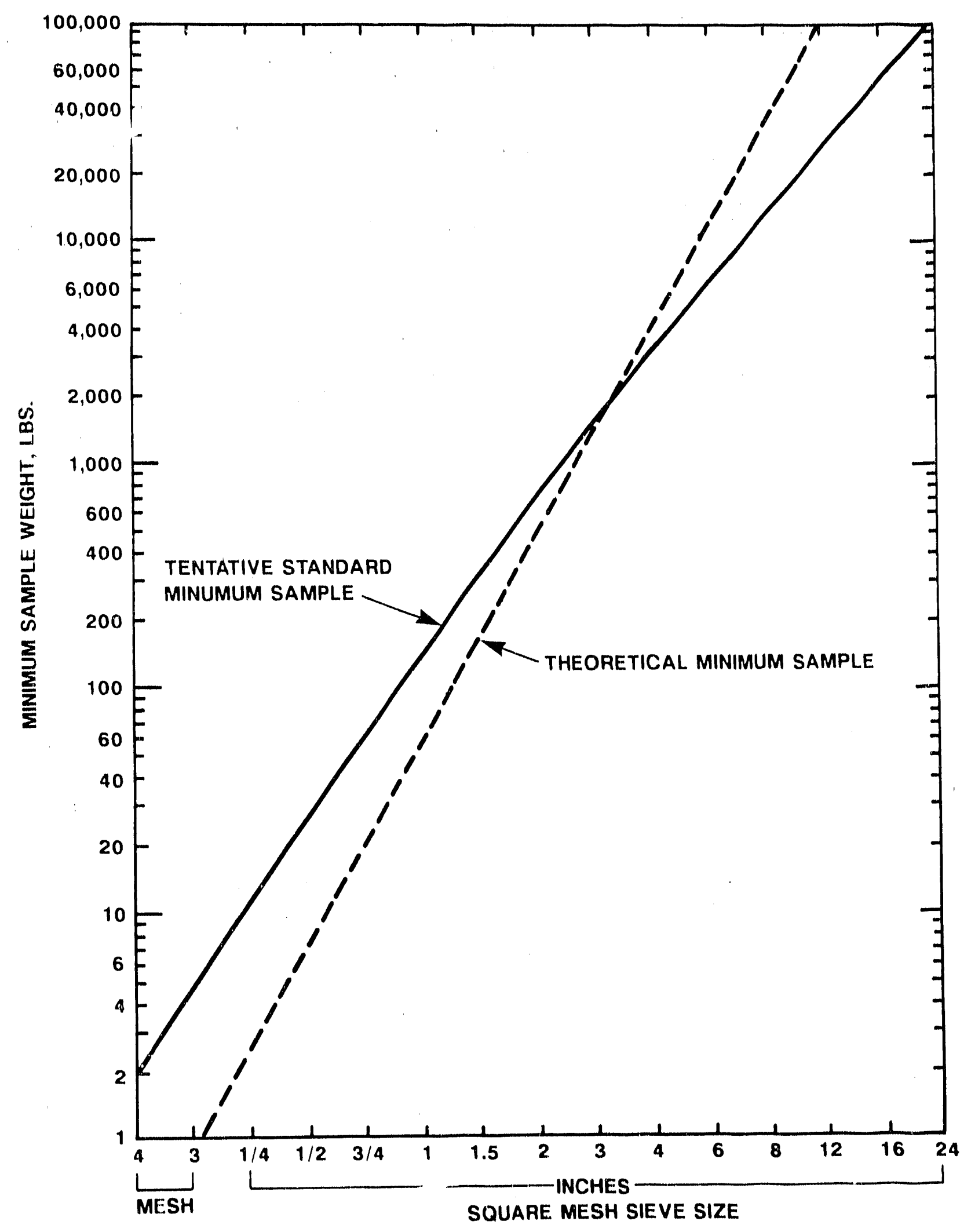

FIGURE 3 SIZE-WEIGHT RELATIONSHIP FOR COAL SAMPLES 
The elght-ton samples were obtained from each mine using bulk sampling bags containing approximately one ton each. The bags were held open and loaded using a front-end loader. The samples were secured from three general locations at a given mine, depending on the operating constraints imposed by the particular mine. These sample types are identified as follows:

A. The sample as obtained from the ROM stockplle at the mine preparation facility.

B. In the case of an underground mine producing from multiple seams, samples were obtalned from the ROM conveyor of the destred coal seam.

c. In the case of a surface mine producing from multiple seams, samples were obtained by diverting a haul truck obtaining coal from the desired seam to a remote location of the stockpile area. The samples were then loaded from this dumping area in order to minimize sample contamination.

Table III contains pertinent mine and sample information regarding each of the samples acquilied. Mines are identified as "S" (surface) or "D" (deep) with the sample type identified as discussed above.

The 20, elght-ton coal samples brought back to GR\&DC were split into smaller samples for testing and possible future use. A rigorous splitting procedure was used to ensure that all fractions would be representative of the parent coals.

Sma11 representative quantities of all of the 20 coals were crushed to $14 \times 0$ mesh. A sink/float separation at a 1.3 specific gravity was performed on each coal using "Certigrav" as the heavy liquid. The fractions were dried and subjected to the analyses listed in Table IV. 
Table IV

ANALYSES SCHEDULE (FIRST LEVEL WASHABILITY)

\begin{tabular}{ll} 
Float & Sink \\
\hline$x$ & $x$ \\
$X$ & $x$ \\
$X$ & $x$ \\
$X$ & \\
$X$ & \\
$X$ & \\
$X$ & \\
$X$ & \\
$X$ & \\
$X$ &
\end{tabular}

Test

Ash Composition

$\%$ Ash

Btu

$\%$ sulfur

Sulfur Forms

Acetic Acid Sol. Alkáli

$\%$ Recovery

$\because$ Volatile Niatter

Free Quartz

Ash Fusibility Temp. in

Red. Atm. 


\section{Preliminary Screening Tests}

Raw Coal Data

As mentioned previously, initial review of the properties of the 20 selected coals had been carried out using information supplied by the respective coal companies or obtained through the open literature. After selection and procurement of the 20 selected coals (eight-ton iots), each coal was analyzed again to ensure against large discrepancies in expected coal properties and actual coal properties. The results of this analys is indicated acceptable agreement between the data sets. The analytical results for the raw coal are presented in Table $V$.

As can be seer from Table $V$, the selected group of preliminary coals covers a broad range of characteristics ensuring a reasonable representation of the available bituminous coal supply. The majortty of coals listed in the table are normally cleaned before sale. However, the run-of-mine analyses show a wide range (approximately 40 percent to 5 percent) of ash contents. The volatile matter (dry) shows a similarly large varlation ranging from 41 to 18 percent.

Based on the results shown in Table $V$, most of the coals meet the 'requirements' presented in Table I (Typical Boller Fuel Quality...). The Pocahontas No. 3 and Illinois No. 5 coals have FC/VM Values higher than 2.2. Several of the coals have a high sulfur content. Most noticeable among these are the Western Kentucky and Illinois coals.

Test Results

Representative samples of the run-of-mine coals were crushed to minus 14 mesh and subjected to separation at a specific gravity of 1.3. The 1.3 float fractions were subjected to the various tests described in Table IV. The results of these tests are presented in Table VI, including the proximate and sulfur forms analyses for the 1.3 float fraction. A proximate analys is of the sink fractions is presented in Table VII for completeness. The ash content of 
Table V

RESULTS OF RAW COAL ANALYSIS (RUN-OF-MINE)

\begin{tabular}{|c|c|c|c|c|c|}
\hline $\begin{array}{l}\text { Coal } \\
\text { Seam } \\
\end{array}$ & $\begin{array}{c}\text { Ash } \\
\% \text { dry } \\
\end{array}$ & $\begin{array}{l}V M \\
\% \text { dry }\end{array}$ & $\begin{array}{l}\text { Sulfur } \\
\% \text { dry }\end{array}$ & $\begin{array}{l}\text { Heating Value } \\
\text { (Btu/1b) dry }\end{array}$ & $\begin{array}{c}\text { Moisture } \\
\% \text { AR }\end{array}$ \\
\hline $\begin{array}{l}\text { Cedar Grove } \\
\text { Lower Elkhorn } \\
\text { Black Creek } \\
\text { Splash Dam } \\
\text { Kentucky \#11 } \\
\text { Lower Kittanning } \\
\text { Pittsburgh \#8 (OH) } \\
\text { Upper Freeport } \\
\text { Kentucky \#9 } \\
\text { Waynesburg \#2 Split } \\
\text { Pittsburgh \#8 (PA) } \\
\text { No.2 Gas } \\
\text { Castle Gate 'D' } \\
\text { plus Sub-seam 3 }\end{array}$ & $\begin{array}{r}4.70 \\
11.16 \\
6.27 \\
21.73 \\
20.84 \\
13.40 \\
14.18 \\
18.55 \\
11.26 \\
9.83 \\
17.03 \\
34.03 \\
14.05\end{array}$ & $\begin{array}{l}35.79 \\
30.85 \\
33.57 \\
27.15 \\
26.01 \\
31.51 \\
34.47 \\
32.34 \\
39.52 \\
30.77 \\
32.49 \\
24.65 \\
40.86\end{array}$ & $\begin{array}{l}0.59 \\
0.68 \\
1.20 \\
0.57 \\
4.70 \\
0.79 \\
1.37 \\
1.18 \\
4.73 \\
2.13 \\
2.25 \\
0.85 \\
0.48\end{array}$ & $\begin{array}{l}14,6,37 \\
13,685 \\
13,798 \\
11,822 \\
11,188 \\
13,113 \\
12,331 \\
12,290 \\
12,810 \\
13,914 \\
12,448 \\
10,195 \\
12,384\end{array}$ & $\begin{array}{l}3.29 \\
4.99 \\
0.96 \\
3.30 \\
9.15 \\
3.93 \\
7.50 \\
4.97 \\
8.42 \\
3.37 \\
4.40 \\
4.26 \\
3.52\end{array}$ \\
\hline $\begin{array}{l}\text { Hazard \#4 } \\
\text { Elkhorn } \# 3 \\
\text { I11inois \#6 } \\
\text { I11inois \#5 } \\
\text { Mary Lee } \\
\text { Pocanontas \#3 } \\
\text { Jaw Bone }\end{array}$ & $\begin{array}{l}40.00 \\
28.08 \\
17.55 \\
19.77 \\
38.95 \\
22.92 \\
33.08\end{array}$ & $\begin{array}{l}27.41 \\
29.68 \\
35.75 \\
35.02 \\
23.65 \\
17.97 \\
20.03\end{array}$ & $\begin{array}{l}1.07 \\
1.47 \\
3.92 \\
4.74 \\
0.76 \\
0.76 \\
0.69\end{array}$ & $\begin{array}{r}8,381 \\
10,542 \\
11,372 \\
11,102 \\
8,667 \\
11,532 \\
10,228\end{array}$ & $\begin{array}{r}9.12 \\
5.64 \\
10.06 \\
8.55 \\
5.24 \\
9.30 \\
5.34\end{array}$ \\
\hline
\end{tabular}


PROXIMATE AND SULFUR FORMS ANALYSES OF 1.3 FLOAT FRACTION

Searn
Cedar Grove
Lower Elkhorn
Black Creek
Splash Dam
Kentucky \#11
Lower Kittanning
Pittsburgh \#8 (OH)
Upper Freeport
Kentucky \#9
Waynesburg \#2 Split
Pittsburgh \#8 (PA)
No.2 Gas
Castle Gate 'D'
plus Sub-seam 3
Hazard $\$ 4$
E1khorn \#3
I1linois \#6
Illinois \#5
Mary Lee
Pocahontas \#3
Jaw Bone

\begin{tabular}{|c|c|c|c|c|c|}
\hline $\begin{array}{c}\text { Ash } \\
\% \text { dry }\end{array}$ & $\begin{array}{c}V M \\
\% d r y\end{array}$ & $\begin{array}{l}\text { Sulfur } \\
\% \text { dry } \\
\end{array}$ & $\begin{array}{c}\text { Heating } \\
\text { Value } \\
\text { (Btu/lb) dry }\end{array}$ & $\frac{\text { sulfu }}{\text { Pyrdtct }}$ & $\frac{(W t \%)}{\text { Organtc }}$ \\
\hline $\begin{array}{l}1.56 \\
1.47 \\
2.27 \\
1.78 \\
3.58 \\
2.40 \\
3.73 \\
3.48 \\
4.09 \\
3.20 \\
3.58 \\
3.02 \\
4.18\end{array}$ & $\begin{array}{l}37.06 \\
36.13 \\
35.88 \\
32.67 \\
42.50 \\
37.26 \\
39.39 \\
37.62 \\
43.20 \\
26.07 \\
32.66 \\
34.00 \\
45.78\end{array}$ & $\begin{array}{l}0.60 \\
0.63 \\
0.80 \\
0.61 \\
2.51 \\
0.78 \\
1.02 \\
0.68 \\
2.43 \\
1.54 \\
1.04 \\
0.79 \\
0.55\end{array}$ & $\begin{array}{l}14,935 \\
15,225 \\
14,441 \\
15,184 \\
13,899 \\
15,016 \\
14,018 \\
14,840 \\
13,932 \\
14,941 \\
14,470 \\
14,964 \\
14,059\end{array}$ & $\begin{array}{l}0.02 \\
0.04 \\
0.00 \\
0.08 \\
0.44 \\
0.01 \\
0.16 \\
0.02 \\
0.46 \\
0.31 \\
0.08 \\
0.02 \\
0.02\end{array}$ & $\begin{array}{l}0.58 \\
0.59 \\
0.80 \\
0.53 \\
2.07 \\
0.77 \\
0.86 \\
0.66 \\
1.97 \\
1.23 \\
0.96 \\
0.77 \\
0.53\end{array}$ \\
\hline $\begin{array}{l}3.22 \\
2.64 \\
2.73 \\
2.78 \\
3.20 \\
3.45 \\
4.77\end{array}$ & $\begin{array}{l}41.52 \\
42.96 \\
43.73 \\
43.91 \\
34.37 \\
22.63 \\
26.50\end{array}$ & $\begin{array}{l}0.91 \\
1.06 \\
2.63 \\
2.51 \\
0.84 \\
0.59 \\
0.72\end{array}$ & $\begin{array}{l}14,513 \\
14,861 \\
13,902 \\
13,676 \\
14,472 \\
15,228 \\
15,028\end{array}$ & $\begin{array}{l}0.02 \\
0.15 \\
0.31 \\
0.23 \\
0.00 \\
0.00 \\
0.05\end{array}$ & $\begin{array}{l}0.89 \\
0.91 \\
2.32 \\
2.88 \\
0.84 \\
0.59 \\
0.67\end{array}$ \\
\hline
\end{tabular}


Table VII

ASH AND SULFUR ANALYSES- -1.3 SINK FRACTION

\begin{tabular}{l} 
Coal \\
\multicolumn{1}{c}{ Seam } \\
Cedar Grove \\
Lower Elkhorn \\
Black Creek \\
Splash Dam \\
Kentucky \#11 \\
Lower Kittanning \\
Pittsburgh \#8 (OH) \\
Upper Freeport \\
Kentucky \#9 \\
Waynesburg \#2 Split \\
Pittsburgh \#8 (PA) \\
No. 2 Gas \\
Castle Gate 'D' \\
plus Sub-seain 3 \\
Hazard \#4 \\
Elkhorn \#3 \\
I1linois \#6 \\
I1linois \#5 \\
Mary l.ee \\
Pocahontas \#3 \\
Jaw Bone
\end{tabular}

Coal

Ash

$\%$ dry

11.06

23.18

13.27

33.75

34.35

23.04

27.33

29.60

19.41

13.30

29.41

41.65

17.12

42.88

32.35

18.24

21.98

40.35

25.92

37.02
Sulfur

$\%$ dry

0.52

0.80

1.84

0.48

5.94

0.79

1.87

1.76

7.20

2.50

3.30

0.79

0.45

1.12

1. 51

4.37

4.54

0.75

0.62

0.65
Heating Value (Btu/7b) dry

13,471

11,346

12,620

9,616

8,885

11,569

10,356

10,476

11,429

13,246

10,672

8,600

11,737

8,700

9,719

11,412

11,281

8,544

11,268

9,494 
the 1.3 specific gravity float coals range from approximate $1 y=1.5$ to 4.8 percent, which suggests that not all coals can be cleaned to the required two percent ash level. A reduction in ash content yields a corresponding increase in volatile matter and heating value on an as-received basis. Conversely, sulfur levels are decreased due to the removal of pyrites.

Table VIII presents the results of ash fusion tests as well as a free quartz and soluble alkali analyses. The free quartz content of the ashes range from 4 to 20 percent. All of these values are below the minimum CWF fees specification of 25 percent. Also, the soluble alkali content is below the tolerable limit for a 11 coals and is not a factor for additional consideration. With the exception of the Castle Gate "D" coal sample and the Illinois Nos. 5 and 6 samples, all of the coals have fluid temperatures (reducing) in excess of $2500^{\circ} \mathrm{F}$, which is the minimum value given in the selection criteria. The maximum temperature noted was $2700^{\circ} \mathrm{F}$. If the initial deformation temperature of a coal was greater than $2250^{\circ} \mathrm{F}$, with the fluid temperature being greater than $2500^{\circ} \mathrm{F}$, the coal was judged to be a potential candidate for the first round of tests.

Table IX lists the results of the mineral matter analyses of the ash for the 1.3 float fractions. The $\mathrm{NaO}$ contents of the coals are all within the acceptable range. The $\mathrm{Fe}_{2} \mathrm{O}_{3}$ content of the Kentucky No. 11, Kentucky No. 9, Waynesburg, Castle Gate, Illinois No. 6, and Illinois No. 5 coals all are relatively high.

\section{Discussion of Selection Process}

The criteria for selecting the eight coals have been given previously. To reiterate, they were: ease of separation, estimated recovery of two percent ash, and heating value. 
ASH ANALYSIS -1.3 FLOAT FRACTION

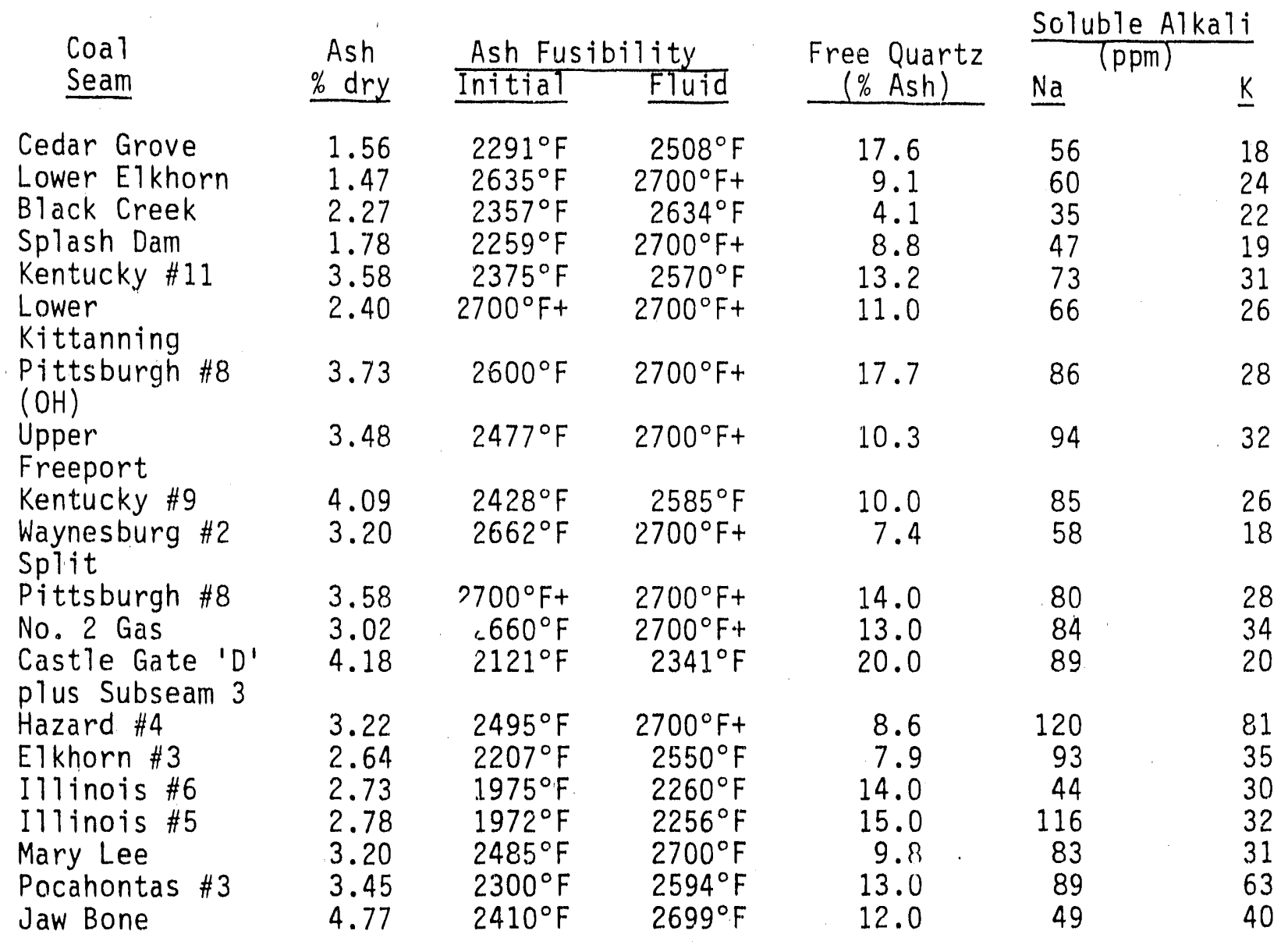


Table IX

ASH COMPOSITION ANALYSIS- -1.3 FLOAT FRACTION

Coal

Mineral Ash Analysis (wt\% dry)

Seam

Cedar Grove

Lower Elkhorn

Black Creek

Splash Dam

Kentucky \#11

Lower

Kittanning

Pittsburgh \#8

Upper

Freeport

Kentucky \#9

Waynesburg \#2

Split

Pittsburgh \#8

No. 2. Gas

Castle Gate D

plus Subseam 3

Hazard \#4

Elkhorn \#3

Illinois \#6

Illinois \#5

Mary Lee

Pocahontas \#3

Jaw Bone

\begin{tabular}{ll}
$\mathrm{SiO}_{2}$ & $\frac{\mathrm{Al}_{2} \mathrm{O}_{3}}{29.25}$ \\
\hline 42.78 & 29.72 \\
54.75 & 26.72 \\
42.39 & 31.29 \\
41.17 & 30.61 \\
46.76 & 21.22 \\
57.94 & 29.87
\end{tabular}

$\mathrm{iO}_{3} \mathrm{Fe}$

2.08

2.01

1.74

2.03

1.72

2.26

$\begin{array}{ll}56.74 & 25.25\end{array}$

$47.74 \quad 29.21$

1.37

1.99

$49.85 \quad 20.82$

47.73

27.43

1.88
1.46

20.08

16.27

1.94

$6.38 \quad 2.94$

$7.49 \quad 1.46$

7.51

9.80

$\begin{array}{ll}17.80 & 1.47\end{array}$

50.26
41.82

45.76

$31.13 \quad 1.91$

9.29

2.74

15.33

37.96

$28.57 \quad 1.62$

46.07

22.79

1.70

18.31

46.64

21.22

1.73

16.26

45.03

30.12

2.67

52.75

24.65

1.48

9.70

7.76

8.13

4.34

1.11

3.651 .36

$3.78 \quad 1.61$

2.66

2.66

1.21

2.62

1.82

1.61

$\begin{array}{lll}51.47 & 27.75 & 1.67\end{array}$

0.60

6.24

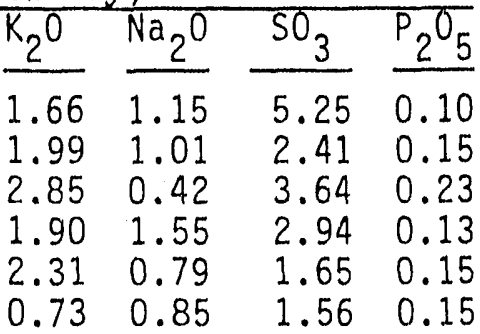

2.15

0.74

0.48

0.21

1.592 .00

0.64

3.08

0.36

$0.70 \quad 2.65$

0.64

1.29

0.07

$0.4 ? \quad 1.88$

0.83

1.06

0.35

1.90

0.78

2.87

0.25

0.42

1.01

1.46

0.09

2.241 .11

$2.00 \quad 1.12$

2.051 .38

$4.37 \quad 0.86$

$2.40 \quad 0.14$

2.140 .46

3.03

0.20

$2.05 \quad 1.08$

2.61

3.09

0.73

2.98

0.78

1.71

0.10

0.20 
The "estimated recovery at two percent ash" was obtained by assuming a linear recovery to ash content relationship. The estimated energy recovery was estimated in like fashion. As shown in Table $X$, the 1.3 float fractions have ash contents ranging from about 1.6 percent to 4.8 percent. The sink material yielded a much greater vartation. Recoveries ranged from one to 70 percent.

Ranking the coals, first by using "estimated recovery at two percent ash," and secondly, the "estimated energy recovery," ylelds expected results. The ranks roughly coincide with the 1.3 float recovery val!nes. Table $X$ lists all 20 coals with the properties which were given priority in making the eight-coal selection. In this table, the coals are ranked in order of preference. The first eight coals were recommended for the detailed study. All of the eight coals listed met the standards set by the selection criteria. It should be pointed out that the mineral analyses of the Kentucky No. 11 ash indicates a high level of $\mathrm{Fe}_{2} \mathrm{O}_{3}$ and $\mathrm{Fe} / \mathrm{Ca}$ as compared to the other coals. These particular characteristics have historically been used to identify coals wh ch give fouling and slagging problems. Nonetheless, this coal was included after additional geographic considerations were made. 
Table $X$

ESTIMATED 2\% ASH RECOVERY

\begin{tabular}{|c|c|c|c|c|c|}
\hline $\begin{array}{l}\text { Coal } \\
\text { Seam }\end{array}$ & $\begin{array}{l}\text { Est. Wt. } \\
\text { Recovery at } \\
2 \% \text { Ash }(\%)\end{array}$ & $\begin{array}{l}\text { Est. Energy } \\
\text { Recovery } \\
\text { at } 2 \% \text { Ash (\%) }\end{array}$ & $\begin{array}{l}\frac{1.3 \mathrm{FI}}{\text { Recovery }} \\
\% \text { Dry } \\
\end{array}$ & $\begin{array}{l}\frac{\text { at Frad }}{\text { Ash }} \\
\% \text { Dry }\end{array}$ & $\begin{array}{l}\text { Btun } \\
\text { DAF }\end{array}$ \\
\hline $\begin{array}{l}\text { Cedar Grove } \\
\text { Lower Elkhorn } \\
\text { Black Creek } \\
\text { Splash Dam } \\
\text { Kentucky \#11 } \\
\text { Lower Kittanning } \\
\text { Pittsburgh \#8 (OH) } \\
\text { Upper Freeport } \\
\text { Kentucky \#9 } \\
\text { Waynesburg \#2 Split } \\
\text { Pittsburgh \#8 (PA) } \\
\text { No.2 Gas } \\
\text { Castle Gate 'D' } \\
\text { plus Sub-seam } 3\end{array}$ & $\begin{array}{l}89.33 \\
78.56 \\
60.93 \\
53.52 \\
38.11 \\
37.73 \\
32.51 \\
25.56 \\
27.85 \\
25.81 \\
23.32 \\
19.34 \\
17.99\end{array}$ & $\begin{array}{l}91.15 \\
89.46 \\
63.77 \\
68.88 \\
42.77 \\
43.20 \\
37.20 \\
30.89 \\
29.11 \\
27.72 \\
27.12 \\
28.39 \\
22.78\end{array}$ & $\begin{array}{l}69.68 \\
5 \% .74 \\
69.15 \\
47.63 \\
68.21 \\
45.27 \\
60.64 \\
44.48 \\
56.96 \\
41.30 \\
41.74 \\
29.21 \\
37.59\end{array}$ & $\begin{array}{l}1.56 \\
1.47 \\
2.27 \\
1.78 \\
3.58 \\
2.40 \\
3.73 \\
3.48 \\
4.09 \\
3.20 \\
3.58 \\
3.02 \\
4.18\end{array}$ & $\begin{array}{l}15,172 \\
15,452 \\
14,777 \\
15,459 \\
14,415 \\
15,385 \\
14,561 \\
15,383 \\
14,526 \\
15,435 \\
15,017 \\
15,430 \\
14,672\end{array}$ \\
\hline $\begin{array}{l}\text { Hazard \#4 } \\
\text { Elkhorn \#3 } \\
\text { Illinois \#6 } \\
\text { Illinois \#5 } \\
\text { Mary Lee } \\
\text { Pocahontas \#3 } \\
\text { Jaw Bone }\end{array}$ & $\begin{array}{r}12.09 \\
9.33 \\
7.11 \\
3.12 \\
2.64 \\
0.90 \\
0.52\end{array}$ & $\begin{array}{r}20.30 \\
12.92 \\
8.70 \\
4.17 \\
4.41 \\
1.19 \\
0.69\end{array}$ & $\begin{array}{r}19.47 \\
12.31 \\
9.71 \\
4.33 \\
4.23 \\
1.55 \\
1.23\end{array}$ & $\begin{array}{l}3.22 \\
2.64 \\
2.73 \\
2.78 \\
3.20 \\
3.45 \\
4.77\end{array}$ & $\begin{array}{l}14,996 \\
15,264 \\
14,292 \\
14,067 \\
14,509 \\
15,772 \\
15,781\end{array}$ \\
\hline
\end{tabular}




\section{SECOND LEVEL SCREENING TESTS}

The elght coals selected after the preliminary washabllity analys is were subjected to a second level of testing to further define benefictation parameters. The results of the second level study were used in selecting the four candidate CWF coals and in identifying appropriate size arid gravity fractions required to produce $7 \%$ and $2 \%$ ash beneficlated coals. A presentation of the data generated during this phase of the screening procedure follows.

\section{Float-And-Sink Data}

The eight coals were subjected to the series of float-and-sink testing and analytical procedures described in Table XI. The tests consisted of gravity separations of three top sizes $\left(1-1 / 2^{\prime \prime} \times 0,3 / 8^{\prime \prime} \times 28\right.$ mesh, and 28 mesh $\left.\times 0\right)$ into seven density fractio.1s, and subsequent analys is of the fractions for moisture, ash, recovery, and heating value (21 samples per coal). All sample preparation and testing was conducted in accordance with applicable portions of the ASTM standards.

\section{Theoretical Recovery}

The results obtained from the float-and-sink procedure just described, were used to project the recovery and corresponding properties for both $7 \%$ and $2 \%$ ash coal. These projections were nade without consideration of plant performance characteristics and, therefore, may be considered ideal to theoretical in nature. $7 \%$ ash quality and recovery characteristics were derived from the data for $11 / 2$ inch $\times 0$ size coal given in the tables and are summarized in Table XII. 
Table XI

\section{SECOND LEVEL WASHABILITY ANALYSES}

Eight Coals--Seven Specific Gravities--Three Top Sizes

Top Sizes

$$
\begin{aligned}
& 1-1 / 2^{\prime \prime} \times 0 \\
& 3 / 8^{\prime \prime} \times 28 \text { Mesh } \\
& 28 M \times 0
\end{aligned}
$$

Gravity Fractions

$$
\begin{aligned}
& 1.25 \text { Float } \\
& 1.25 \times 1.30 \\
& 1.30 \times 1.35 \\
& 1.35 \times 1.40 \\
& 1.40 \times 1.50 \\
& 1.50 \times 1.60 \\
& 1.60 \operatorname{sink}
\end{aligned}
$$

Analyses on all size and gravity fractions (21 Samples per coal)

$$
\text { \% Moisture }
$$$$
\% \text { Ash }
$$

Btu

$\%$ Recovery 
Table XII

THEORETICAL 7\% ASH RECOVERY

$11 / 2$ INCH $\times 0$ MATERIAL

\begin{tabular}{|c|c|c|c|c|c|}
\hline COAL I.D. & SEPARATION & RECOVERY \% & ASH \% & MOIST, \% & $\begin{array}{c}\text { HEATING } \\
\text { VALUE, BTU/\# }\end{array}$ \\
\hline Cedar Grove* & +1.60 & 100.0 & 4.16 & 1.96 & 14750 \\
\hline Lower Elkhorn & 1.57 & 87.1 & 7.00 & 3.19 & 14070 \\
\hline Black Creek* & +1.60 & 100.0 & 5.23 & 3.90 & 13820 \\
\hline Splash Dam & +1.60 & 84.9 & 7.00 & 1.16 & 14410 \\
\hline Lower kitt. & 1.43 & 78.7 & 7.00 & 1.01 & 14300 \\
\hline W. KY \#11 & +1.60 & 95.7 & 7.00 & 2.92 & 12540 \\
\hline Pittsburgh \#8 & 1.50 & 86.4 & 7.00 & 3.89 & 13250 \\
\hline Upper Freeport & 1.37 & 68.4 & 7.00 & 1.76 & 14170 \\
\hline
\end{tabular}


As an ald in cletermining the characteristics of the $2 \%$ ash coal, curves for yteld, cumulattve float ash, and cumulative sink ash were dertved for the $3 / 8$ inch $\times 28$ mesh materlal and are 11 lustrated in Figures 4 through 11. Theoretical properties of the $2 \%$ ash coals are given in Table XIII.

\section{Findings}

Five of the eight coals, Cedar Grove, Lower Elkhorn, Black Creek, Splash Dam, and Lower Kittanning yielded results indicating that $2 \%$ ash recoveries ranging from 25 to 86 percent can be expected under ideal condttions, with a $3 / 8$ inch by 28 mesh gradation. However, two of these coals, Cedar Grove and Black Creek, typically have very low ROM ash contents $(<7 \%$ ) which lead to difficulty in obtaining $7 \%$ ash coal from these sources. 


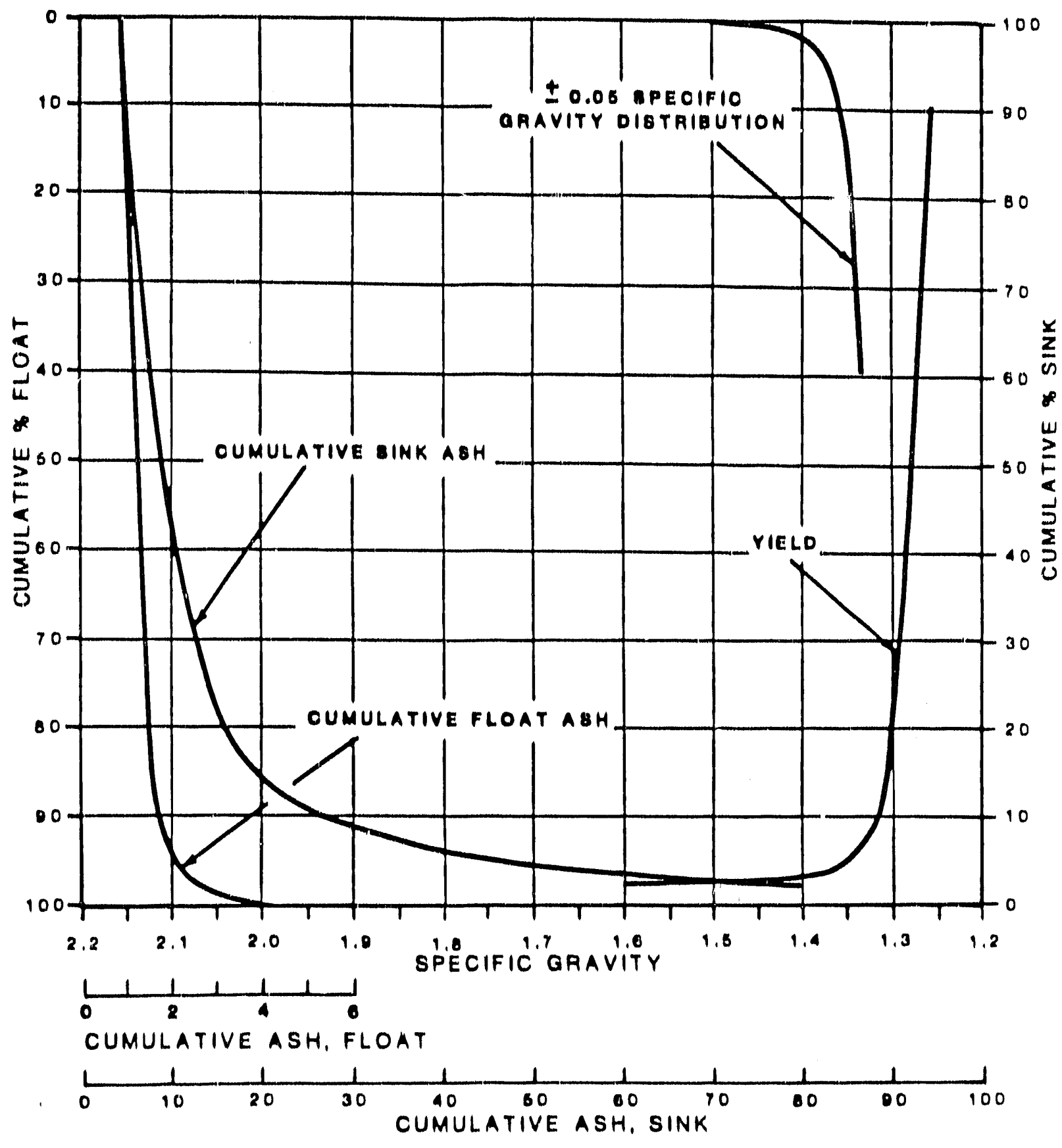

FIGUAE a WASHABILITY CURVES FOR CEDAR GROVE COAL, 3/8" $\times 28 \mathrm{MESH}$ 


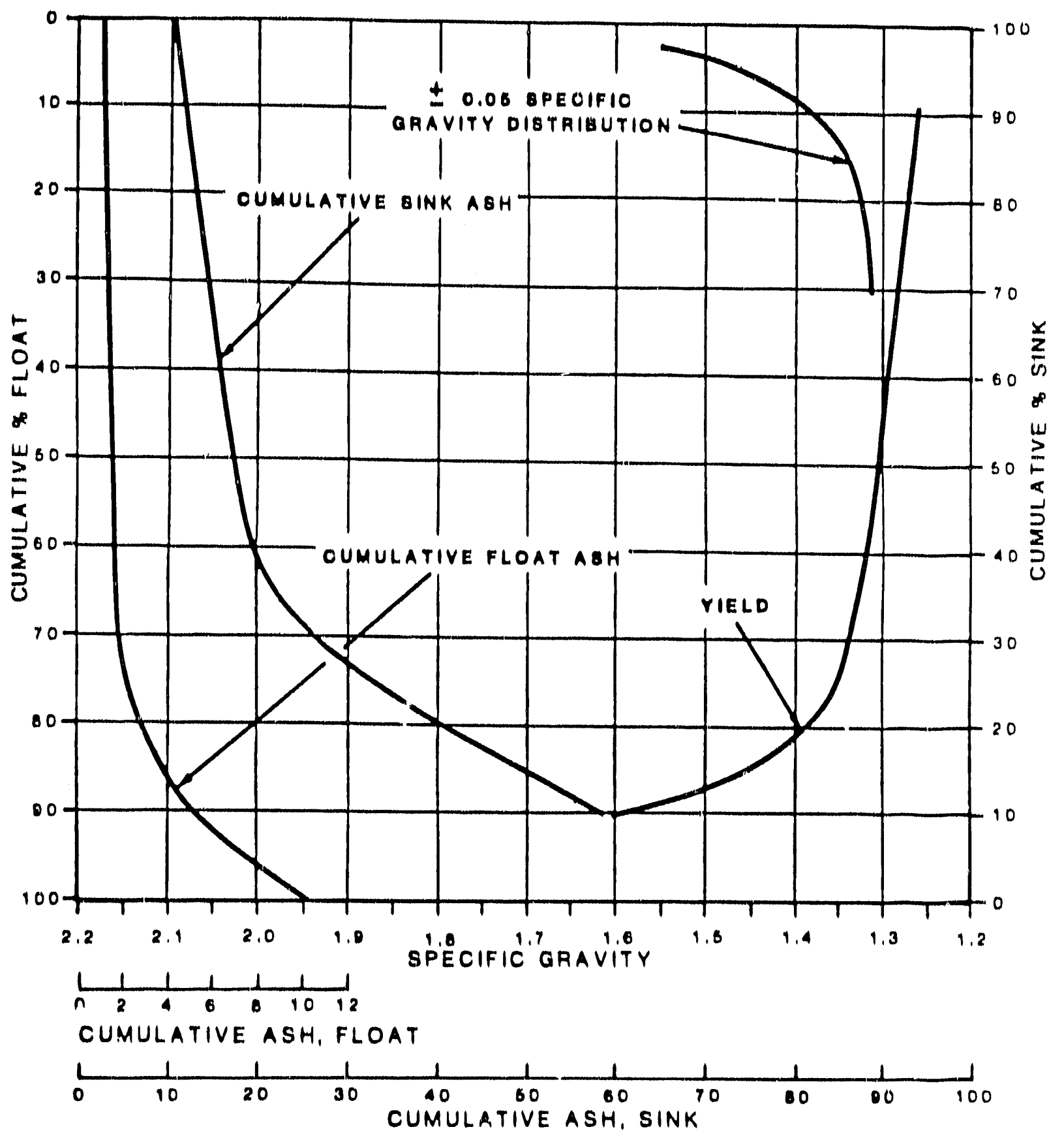

FIGUAE 5 WASHABILITY CUAVES FOR LOWEA ELKHORN COAL, 3/8" $\times 28 \mathrm{MESH}$ 


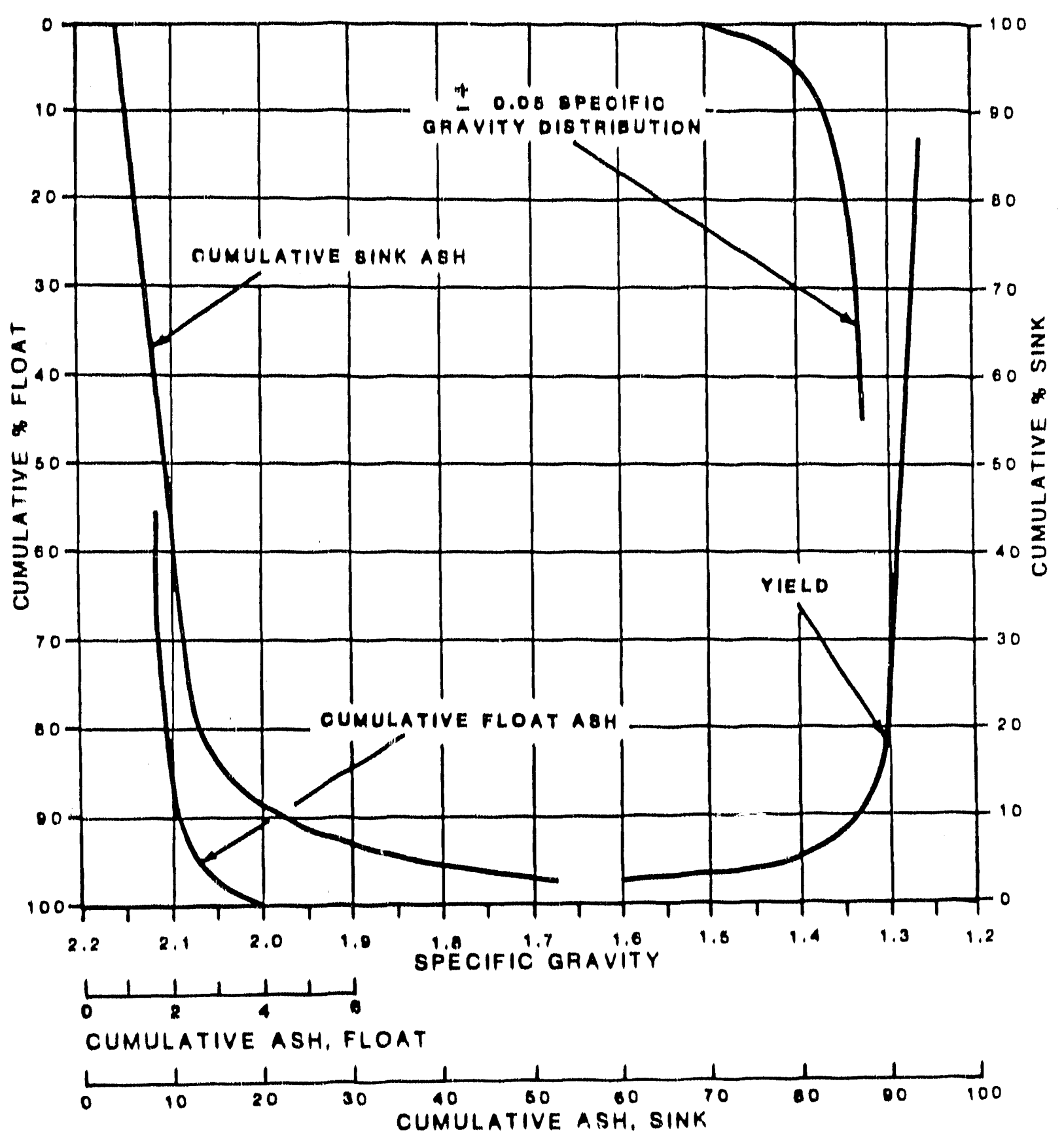

FIGURE 6 WAISHABILITY CURVES FOR BLACK CREEK COAL, 3/8" $\times 28 \mathrm{MESH}$ 


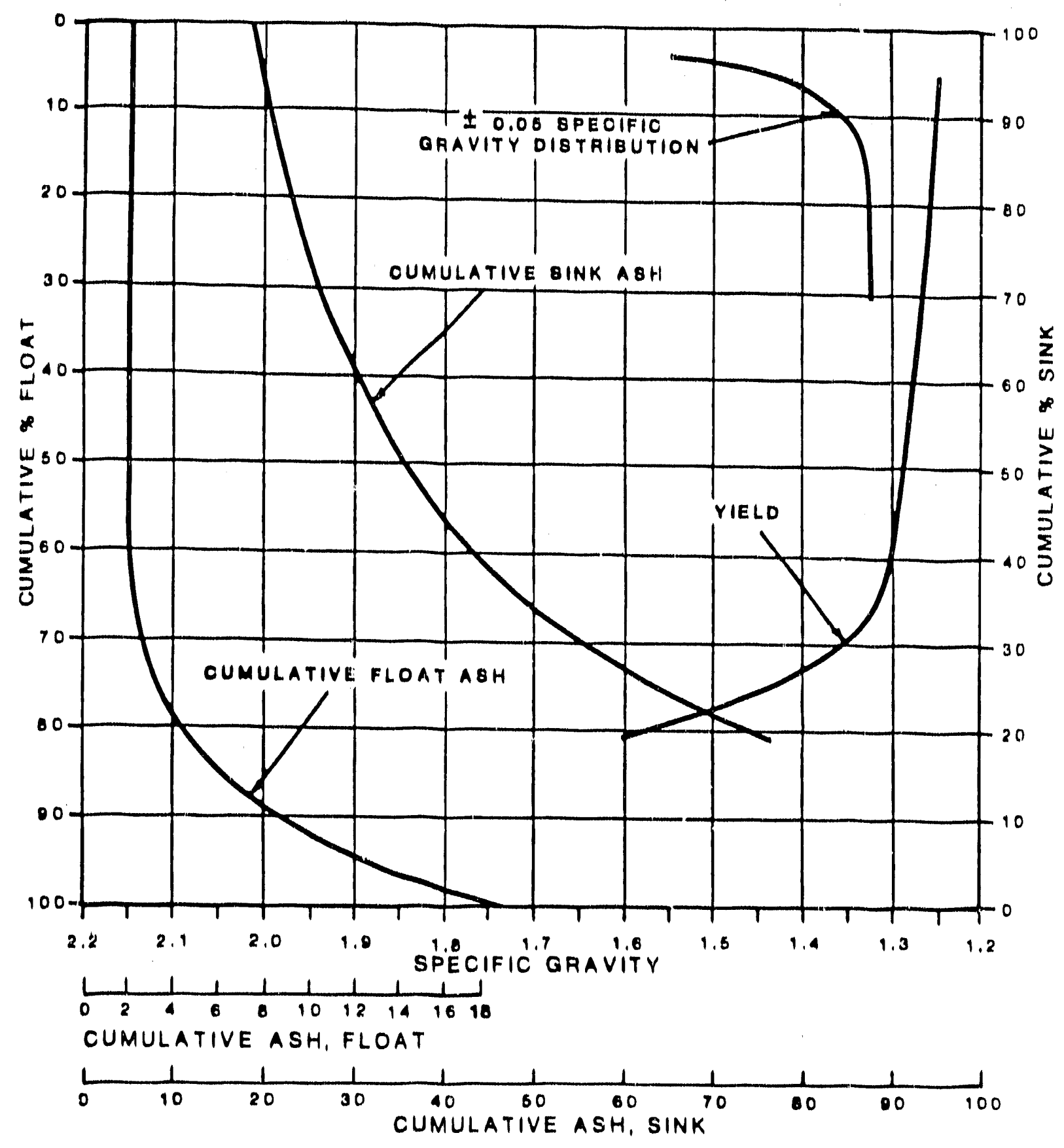

FIGURE 7 WASHABILITY CURVES FOR SPLASH DAM COAL, 3/8" $\times 28$ MESH 


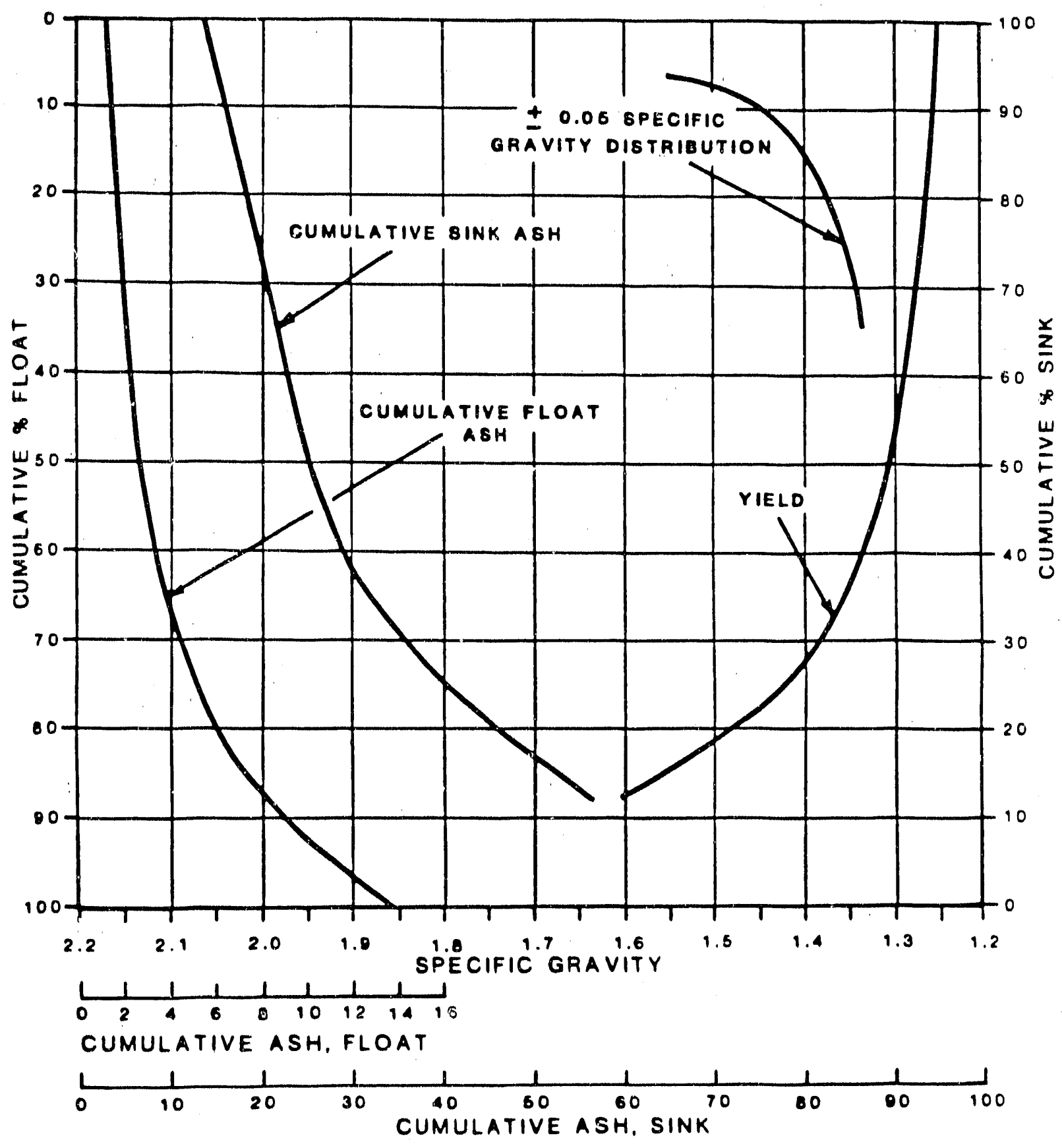

FIGURE 8 WASHABILITY CURVES FOR LOWER KITTANNING COAL, 3/8" $\times 28$ MESH 


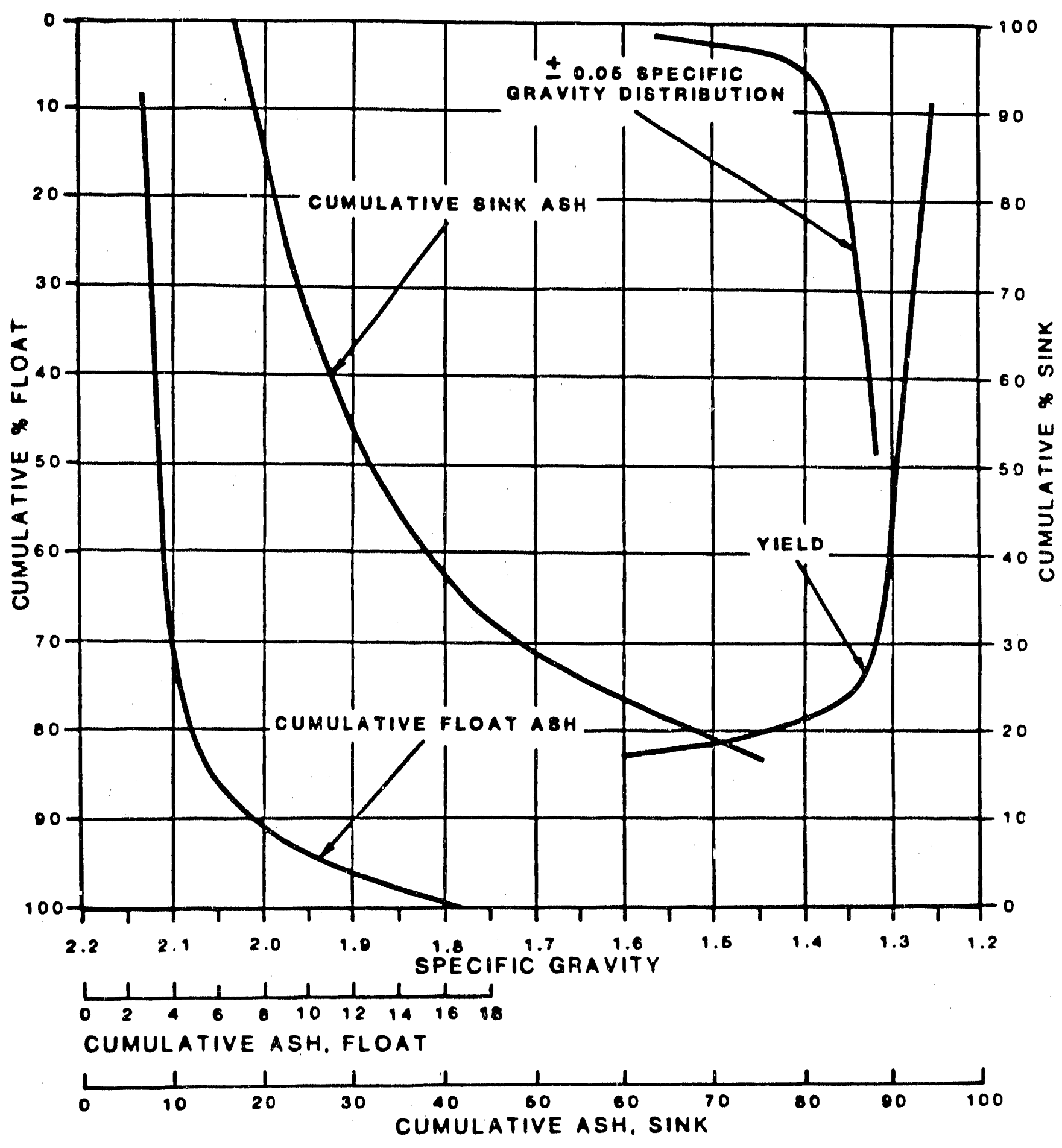

FIGURE 9 WASHABILITY CURVES FOR WESTERN KENTUCKY \#11 COAL, 3/8" × 28 MESH 

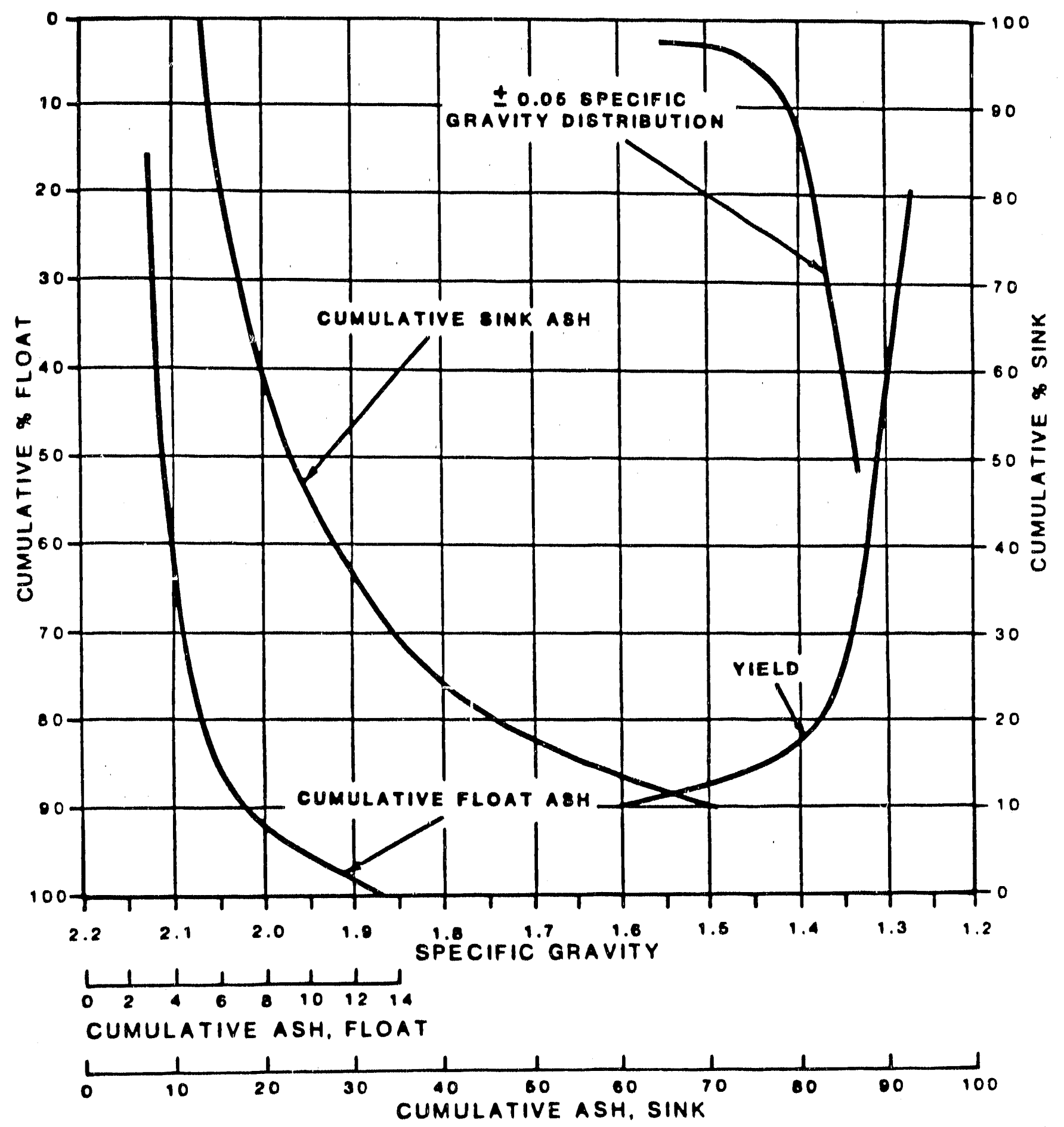

FIGURE 10 WASHABILITY CURVES FOR PITTSBURGH \#8(OH) COAL, 3/8 $\times 28 \mathrm{MESH}$ 


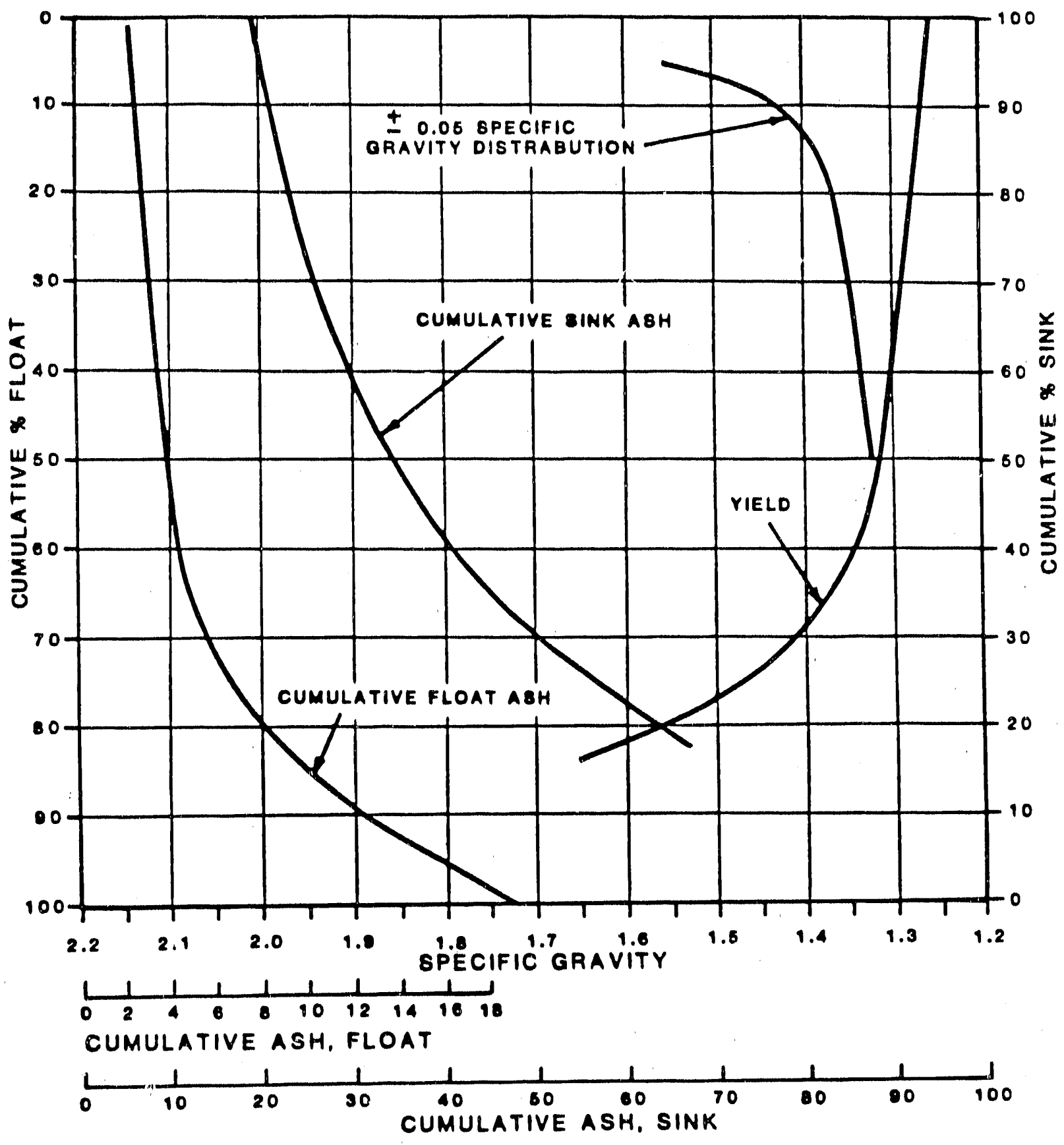

FIGURE 11 WASHABILITY CURVES FOR UPPER FREEPORT COAL, 3/8" $\times 28 \mathrm{MESH}$ 


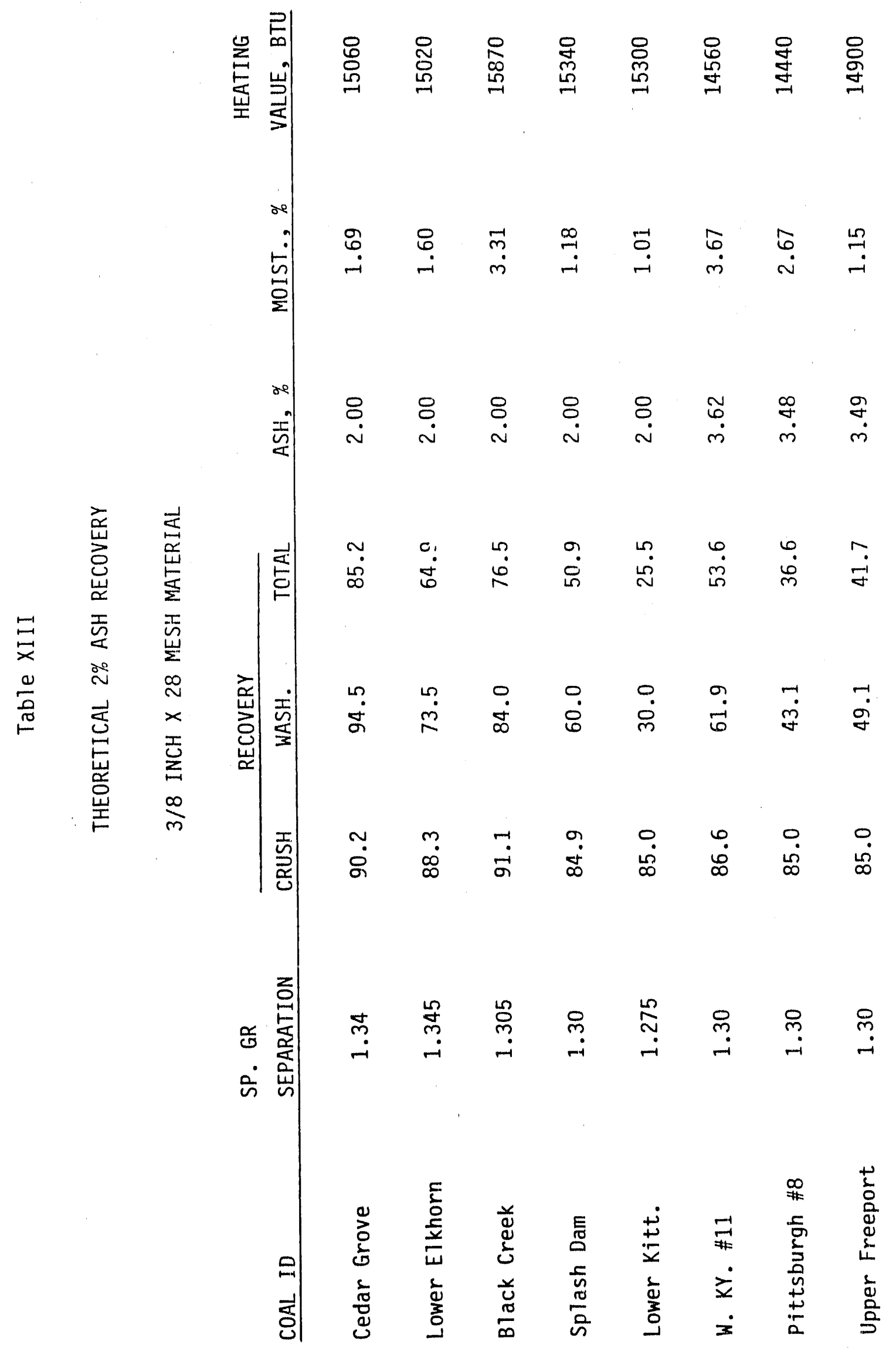




\section{COAL BENEFICIATION}

The purpose of the detailed washability studies was to identify those coals that are capable of being beneficlated to $2 \%$ ash at lowest costs. These coals will probably be separated at or near a 1.3 specific gravity. $2 \%$ ash beneficiation will also include a mineral matter liberation step prior to the gravity separation step. Due to the limitations of fine coal (minus 28 mesh) cleaning at low specific gravities, the coals will be crushed in a manner such that fines production is minimized.

A request for proposal was sent to sixteen potential beneficiators identified in Table XIV. A list of the eight coals, along with available washability data, and the schedule for delivery of each coal was included in the request. Five of the candidate beneficiators responded with formal proposals and cost estimates. Costs for completing the $2 \%$ ash cleaning ranged from $\$ 231,000$ to $\$ 772,000$ and averaged $\$ 490,000$.

\section{Selection of Coal Beneficiator}

Each proposal was reviewed and evaluated based on the factors imposed by overal1 CWF program objectives. Since the CWF program does not include an R\&D effort directed toward coal preparation, acceptable proposals were limited to these employing conventional cleaning methods. Additional factors affecting final selection of the beneficiator are discussed below.

- Facility capabilities and capactties were reviewed relative to their ability to meet the delivery schedule for $2 \%$ ash coal in a timely manner. The facilities' bulk handling and storage capabilities were also given due consideration.

- The geographic location's of the facilities were considered with regard to additional shipping and handling cost that may occur as a result. 
LIST OF CANDIDATE BENEFICIATORS

\begin{tabular}{lll} 
1. & \multicolumn{1}{c}{ Benefictator } & Location \\
2. & McNally Pittsburg, Inc. & Pittsburg, Kansas \\
*3. & Dravo Corporation & Pittsburgh, PA \\
*4. & Iowa State University & Pittsburgh, PA \\
5. & Pioneer Coal Preparation, Ltd. & Ames, Iowa \\
6. & University of Kentucky & Ripley, England \\
7. & Consolidation Coal Co. & Lexington, KY \\
8. & Penn. State University & Pittsburgh, PA \\
*9. & Michigan Tech. University & University Park, PA \\
*10. & Colorado School of Mines & Houghton, Mich. \\
11. & Armco Coal Co. & Golden, Co \\
*12. & Mountain States R\&D Co. & Middletown, Ohio \\
13. & Battelle Memorial Institute & Tucson, AZ \\
14. & Bituminous Coal Research Institute & Columbus, Ohio \\
16. & Electric Power Research Institute & Monroevilie, PA \\
15. & Homer City, PA \\
16 & Morgantown, W. VA.
\end{tabular}

* Submitted formal proposals

**Responded as a part of Dravo's proposal 
The avallability of the plants were reviewed in order to anticipate project delays or plan necessary lead rimes required.

o The beneficiators' plant performance history and staff experience were examined in order to provide reasonable insight into performance that can be expected for this project.

The proposal submitted by the Energy and Minerals Resources Research Institute of Iowa State University (ISU) was selected as best fitting all the factors previously discussed. ISU proposed a relatively simple, commerclally used cleaning circuit that offers a controlled performance at low specific gravity separations. Detalls of this proposal are discussed in the following section.

\section{Coal Cleaning Methods}

7\% Ash Coal

Generally, adequate supplies of $7 \%$ ash coal are being produced in commercial coal preparation facilities. These facilities normally provide this cleaned product from a blend of different coal sources or seams. For purposes of this program, where a particular seam is to be isolated as the coal source, special handling arrangements were made with the company operating the cleaning facility in order to meet this requirement.

\section{$2 \%$ Ash Coal}

As previously mentioned, ISU was selected as the $2 \%$ ash beneficiator for this program. The coal was acquired in the $7 \%$ ash range from the commercial cleaning plant and shipped either by truck or rail to the ISU pilot preparation facility at Ames, Iowa. Less than carload lots were delivered by truck; larger shipments were delivered by rail in hopper-bottom cars. To prevent contamination with other coal, each rail shipment was unloaded with an under-car conveyor with delivery directly into trucks. The coal was placed on a hard-surface lot for storage. 
ISU personnel collected a head sample and arlalyzed for molsture, ash, total sulfur, and heating value. A second sample was crushed to a nominal 1/4 inch top size, float-sink tested at several speclfic gravities, and analyzed for molsture and ash to ald in predicting plant performance. Based on these analyses, expected yleld, and previous experfence, a target speclfic gravity of separation was established for cleaning the coal.

The coal was crushed in a once-through impact mill to a nominal top size of $1 / 4$ inch and cleaned in an eight-inch heavy-media cyclone circult (see figure 12). The circult scalps any plus $3 / 8$ inch material for recrushing and deslimes the cyclone feed at $1 / 2 \mathrm{~mm}$. Present drain and rinse screens and magnetic separators do not perform acceptably if the feed is not desitmed.

After approximately 15 minutes of operation at a five-ton per hour feed rate, samples of the product and refuse were collected; the clean coal was analyzed for molsture and ash content, and the yteld to clean coal was determined. The quality and yield of the product were compared to the desired results. As necessary, the heavy-media denilty was adjusted and the test repeated. When desired product quality was attained in a preliminary test, the remainder of the coal was processed without varying operating conditions and samples of the product and refuse collected periodically.

\section{Expected Clean Coal Properties}

Typically, the distribution curve is used to evaluate the efficiency of a given coal-cleaning device. This curve is derived by plotting the percentage of each density fraction of the raw coal that was recovered in the washed coal against the mean densities of the density fractions. Once this curve has been experimentally obtained, it can be used in conjunction with the washability data for a raw coal to predict both the yield and quality of the cleaned coal. 


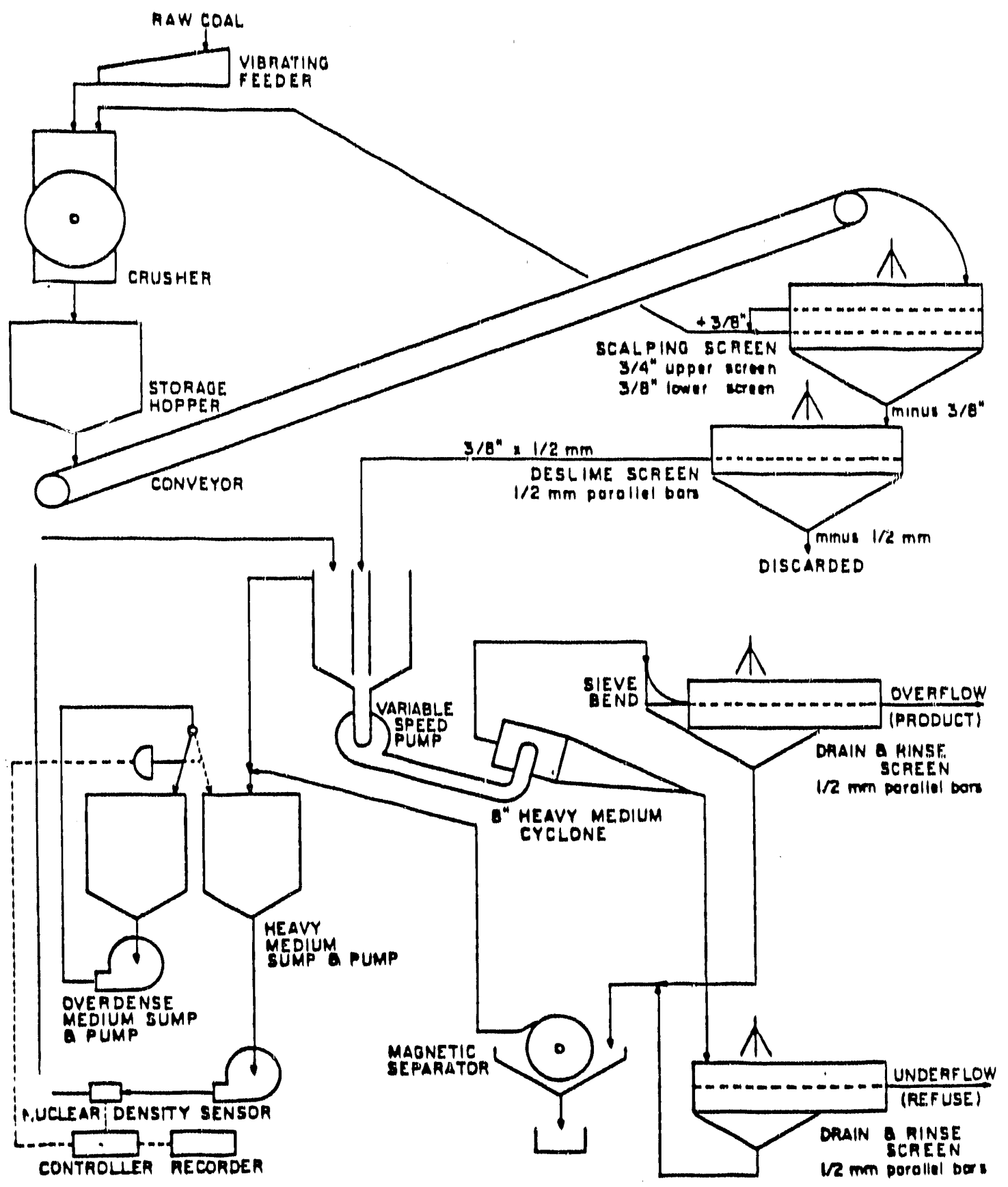

FIGURE 12 HEAVY MEDIUM CYCLONE CIRCUIT 
The curve shown in Figure 13 is the distribution curve for the efghtalnch cyclone at ISU, operating at a low spectftc gravity. This curve was used in conjunction with the washabllity data derived for each of the elght coals selected for this program. Table XV provides a summary of the estimated ytelds and qualtties of each of these coals for a $3 / 8$ inch $\times 28$ mesh particlemsize distribution. Results indicate that five of the elght coals can be used as suttable feeds for producing a $2 \%$ ash product, al though the Lower Kittanning coal was marginal in this respect. 


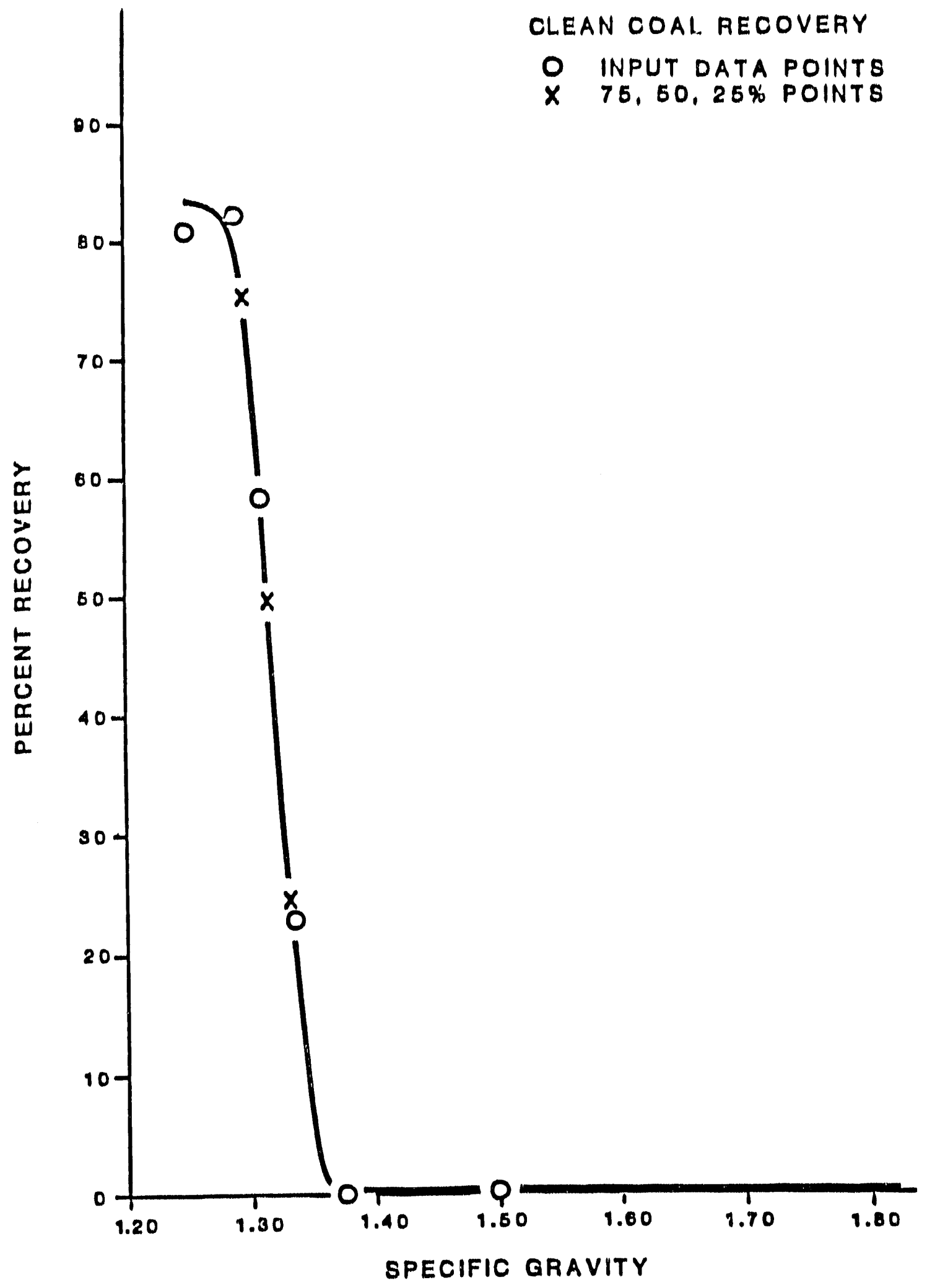

FIGURE 13 ISU 8.INCH CYCLONE DISTRIBUTION CURVE 


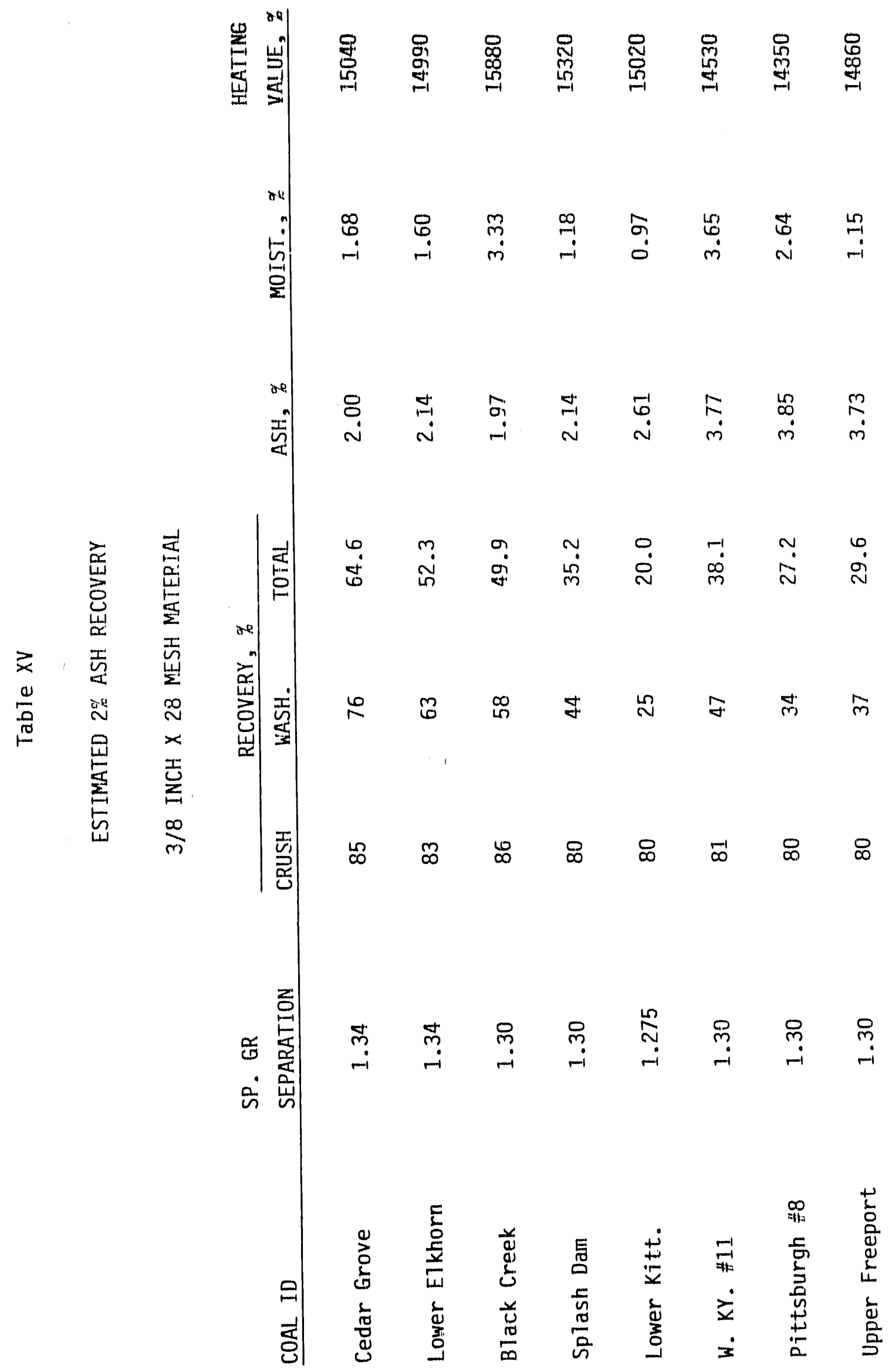




\title{
CWF SELECTION
}

The sultabllity for the manufacture of coal water fuels was determined by the vendors utllizing thetr proprietary processes. The generallzed candidate coal ratings are shown in Table XVI.

\section{Fuel Spectfications}

The specifications developed for the test CWFs were primarlly designed to address anticlpated user's needs. Flve bastc slurry characteristics were addressed:

\author{
Soltcis loading \\ Particle topsize \\ Rheology \\ Uniformity \\ Stability
}

Since testing procedures used in characterization of CWF had not been fully developed, the criteria used to define certain slurry properties are expected to be further refined. The specifications shown in Table XVII are based upon information which in several areas was 1 imited. However, while the actual values and analytical techniques used to measure those slurry properties may vary, user's speciffcations in these areas are believed to be necessary. (Actual test fuels varied from these targets, as described in Volumes 3,4 , and 5.)

A solids loading specification was imposed to ensure test CWFs were representative of commerclal products. Soltds loading was generally determined by measuring molsture content. A range of 68 to $70 \%$ solids was established based upon a survey of commercially avallable CWFs. If all other properties are held constant, the benefits of higher solids loading are obvious. However, there are generally trade-offs between solids loading and CWF viscosity. 

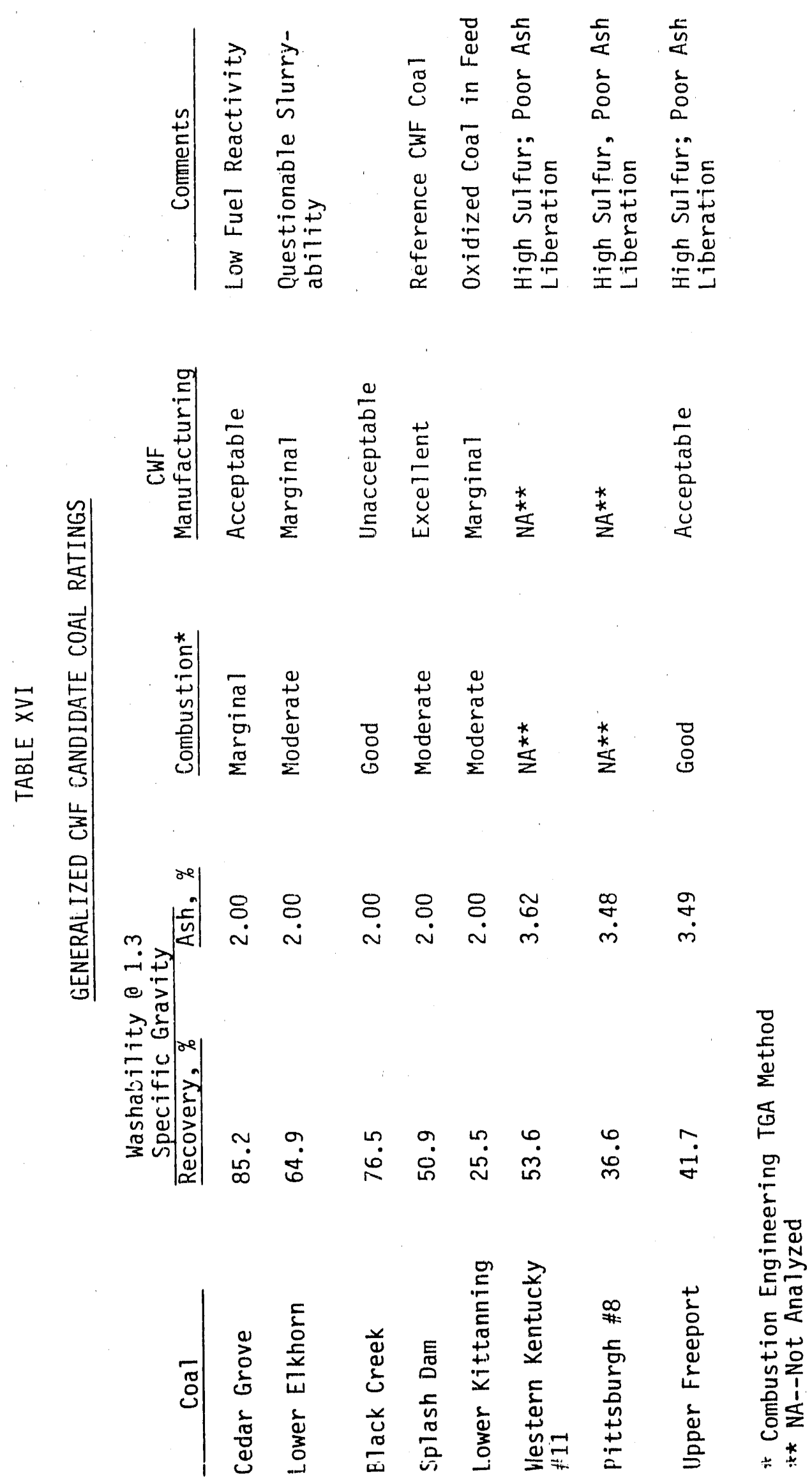
PROPOSED SPECIFICATIONS FOR COAL WATER FUELS

PERCENT SOLIDS: $\quad 68-70 w t \%$

MAXIMUM PARTICLE SIZE: Less than $0.0009 \%$ on 30 Mesh Screen

Less than $0.050 \%$ on 60 Mesh Screen

Less than $0.30 \%$ on 100 Mesh Screen

VISCOSITY:

1) Less than $2800 \mathrm{mPa} . \mathrm{s}$ (1) $100 \mathrm{sec}^{-1}, 20^{\circ} \mathrm{C}$ (Haake method).

2) Less than or equal to 1.1 power factor over shear range of 10-100 reciprocal seconds (Haake method).

pH:

7.5 to 9.0

STABILITY:

When the CWF is delivered, it must be pumpable; it must not be hardpacked.

UNIFORMITY:

Upon completion of preparation of the CWF, and following agitation or circulation if necessary, its total solids content shall not differ by more than $0.6 \%$ between the top $10 \%$ and the bottom $10 \%$ in each tank. Uniformity should last 60 days,

TOXIC COMPONENTS:

A11 toxic and/or hazardous components must be identified and their concentrations must be stated.

The concentration of each toxic component must not exceed OSHA- or EPA-estabiished 1 imits.

NOTE:

The use of alkali metal salt additives is not recommended. 
Specifications of fuel rheological properties are needed to predict pumping and atomization requirements. Unfortunately, CWF rheological characteristics are very complex and extremely difficult to predict. The most widely accepted viscosity measurement technique employs a Haake viscometer. This technique appears to provide good precision and consistent results at relatively low (100 $\mathrm{sec}^{-1}$ ) shear rates. A maximum CWF viscosity of $2800 \mathrm{mPa} . \mathrm{s}$ at $100 \mathrm{sec}^{-1}$ was specified using this technique. In addition, since CWF generally does not exhibit Newtonian characteristics, the rate of viscosity increase as a function of shear rate was considered. If the viscosity/shear rate' relationships are described as a power law function,

$$
\mu=k Y^{n-1}
$$

where $\quad \begin{aligned} \mu & =\text { apparent } \text { viscosity } \\ Y & =\text { shear rate } \\ K & =\text { flow consistency index } \\ & n=\text { flow behavior index }\end{aligned}$

Then $n$ is a measure of the change in viscosity with shear rate. CWFs with flow behavior index exponents less than 1.0 are pseudoplastic (viscosity decreases with shear rate), and those with exponents greater than 1.0 are dilatant (viscosity increases with shear rate).

Extrapolation of the Haake viscosity data to predict atomization behavior at shear rites roughly two orders of magnitude higher is questionable, and present data do not show reliable correlation. The primary use of this low shear rate data is to estimate pumping characteristics. (Evaluation and development of high shear viscosity measurement techniques was being conducted by several organizations, and methods have since been proven.)

Identification of any toxic or hazardous substances contained in the CWF is necessary in order to ensure proper shipping, handling and disposal procedures. In general, CWF has been shipped and handled as nonhazardous materia1. The recommendation against alkali metal additives is an attempt to circumvent the deleterious effect of sodium based additives upon slagging and fouling tendencies of the coal mineral matter. 
Slurry stability is a very broad category addressing changes in slurry properties with time. Various laboratory techniques have been developed to assess static rates. Although the need for long term static storage is still uncertain, an indication of settling rates and agitation requirements is necessary. Key characteristics such as settling with hardpack and substantial changes in viscosity with time are information essential for appropriate handling and utilization. The shear history to which a CWF is exposed can also have a significant effect on rheological properties. Information concerning the sensitivity of a slurry to shear is also very valuable.

A series of analyses were carried out on selected CWFs by $C-E$ and GR\&DC, and correlations were later made between this information and actual performance. The characterization tests are listed in Table XVIII and a brief description of the procedures in Table XIX.

At the beginning of the project, CWF vendors were sent letters of invitation to participate and proposed specifications (Table XVII). Also, visits were made to facilities of prospective suppliers. The vendors chosen were Advanced Fuels Technology (Sohio), Atlantic Research Corporation, Coal Liquids, Ergon and OXCE Fuel Corporation. These vendors felt that the proposed specifications were unrealistic, especially for CWF made from coals not previously used by them. The vendors would, however, make a best effort to meet the program goals. Each manufacturer had a quality control program to ensure the integrity of their products, and CWF for this project was ordered on that basis with the specifications being designated as desired properties.

\section{Reference CWF Selection}

In the project plan, a "reference slurry" was to be chosen as early as possible which would be representative of an average CWF for the purpose of testing various burner designs. The first coal chosen for this CWF was the Lower Kittinning from the Armco Coal Company, Mine No. 25, Montcoal, West Virginia. 


\section{CHARACTERIZATION TESTS FOR COAL WATER FUELS}

Gulf Research \& Development

Percent Solids

Density

Particle Size Distribution

Viscosity

Variable Shear Rate

Constant Shear Rate

Effect of Temperature Change

(Freeze-Thaw)

Settling Rate, $20^{\circ} \mathrm{C}, 40^{\circ} \mathrm{C}, 60^{\circ} \mathrm{C}$

Aging

Aggiomeration

Abrasiveness

Corrosion
Combustion Engineering

Proximate

Ultimate

Higher Heating Value

Flammability Index

Ash Composition

Ash Fusibility

Sulfur Forms

Thermo-Gravimetric Analys is

Weak Acid Leaching

Scanning Electron Microscopy 
TABLE XIX

PROCEDURES FOR CHARACTERIZATION OF CWF

Analysis

Solids

Density

Particle Size Distribution

Viscosity

\section{Procedure}

A $10 \mathrm{~g}$ sample was weighed into a disposable

$57 \mathrm{~mm}$ aluminum dish and heated (o $100^{\circ} \mathrm{C}$ (c) $15^{\prime \prime}$ vacuum with small nitrogen flow unt 11

constant weight was achleved (minimum 2 hours).

A Fisher pycnometer was utilfzed at amblent temperature.

A $1000 \mathrm{~g}$ sample was diluted 1:1 with water and wet sieved through a series of screens $(30,60,100$, and 200 mesh $)$. The screens were dried at $110^{\circ} \mathrm{C}$, the matertal on the screens weighed and reported as \% on the respective screen.

The particle size distribution of the -200 mesh material was determined with a Leeds \& Northrup Microtrac (7991-02) instrument.

A Haake RV-100 with an MVIII sensor system was utilized, over a shear rate range of $0-190 \mathrm{sec}^{-1}$, at $20^{\circ}, 30^{\circ}$ and $40^{\circ} \mathrm{C}$. Three flow curves at each temperature were recorded and data collected from the third acceleration curve. From this curve the viscosity at $100 \mathrm{sec}^{-1}$ and the power law factor were calculated. A constant shear flow curve is also obtained at $100 \mathrm{sec}^{-1}$. $V$ iscosity at higher shear rate ranges 
TABLE XIX (CONT'D.)

PROCEDURES FOR CHARACTERIZATION OF CWF

Ana lysis

Effect of Temperature Change (Freeze-Thaw)

Settling Rate

Aging

Agglomeration

Abrasiveness
Procedure

(5000 $\mathrm{sec}^{-1}$ ) was determined by

Adelphi Center for Energy Studies.

The CWF was subjected to three freeze-thaw cycles and then settling rate, viscosity and particle size distribution determined.

Settling rates of $20^{\circ} \mathrm{C}$ and $40^{\circ} \mathrm{C}$ were determined by perfodically analyzing samples from the top, middle, bottom and drain of a $65 \times 7.5 \mathrm{~cm}$ jacketed column. Settling rate at $60^{\circ} \mathrm{C}$ was determined by heating 1 liter container of the CWF for seven days and analyzing the top, center and bottom for solids content. Viscosity of total samples was also determined at $20^{\circ} \mathrm{C}$.

Five-gallon containers were periodically observed for amount and nature of sediment.

The particles retained on the screens from the particle size determination were photographed through a microscope (20X) and their physical composition observed.

A five-gallon sample was circulated in a pump loop for five hours and the abrasion of test elements determined. 
TABLE XIX (CONT'D.)

PROCEDURES FOR CHARACTERIZATION OF CWF

Analysis

Corrosion

Flammability Index

Thermo-Gravimetric Analysis

Weak Acid Leaching

\section{Procedure}

Carbon and 316 stainless steel coupons were exposed to the CWF for periods ranging up to 100 days, After exposure, weight loss and physical appearance changes were determined.

A measurement of the fgnition temperature of a pulverized fuel in an oxygen atmosphere. This is a relative measurement which is a direct indicator of a pulverized fuels ignition stability and turndown characteristics.

A C-E in-house procedure used to assess fuel reactivity/char burnout characteristics. A $5 \mathrm{mg}$ char sample (prepared either by ASTM D-271 volatile matter determination or in a Drop Tube Furnace systeml) is burned isothermal1y at $700^{\circ} \mathrm{C}$ in air atmosphere. The weight loss of the sample is measured as a function of time. This thermogram is used to predict combustion efficiency.

A pulverized fuel sample was leached in a diluted solution of acetic acid at a controlled $\mathrm{pH}$ for 30 minutes. After the leaching period the slurry was filtered and the leachate analyzed. These data indicate the concentration of active alkali in the coal and can be used in assessing fouling potential. 
The overall approach for selecting a coal for CWF was to select run of mine coals that met the combustion and cleanability criteria and then submit them for vendor evaluation. Upon approval by the vendor, large quantities of the coal cleaned to $7 \%$ ash would be purchased and sent to the varlous vendors for production of 20 gallon batches. These small batches were to meet the proposed set of specifications which included a minimum solids loading of $70 \%$ and a maximum viscosity of $2800 \mathrm{mPa}$.s at $100 \mathrm{sec}^{-1}$. A 1-1/2 ton ROM sample of Lower Kittanning coal was sent to one producer, where a stable CWF was produced containing $70.8 \%$ solids and having acceptable rheological properties. On the basis of these results, 800 tons of the Lower Kittanning coal were purchased and cleaned to an ash level of $6.4 \%$ in a heavy medla plant with a fine coal circuit employing froth flotation. Appropriate quantities of the cleaned coal were sent to four commercial CWF manufacturers. None could produce an acceptable CWF at the requited $70 \%$ solids loading. One vendor, based on previous experience, was able to produce a stable CWF at $66 \%$ solids loading that stored, pumped, atomized and combusted we11 (Table XX).

The other vendors were not asked to investigate or develop a formulation to solve the problem. During this development effort, it was found that the beneficlated coal was much more oxidized and exhibited a $2 \%$ higher equilibrium moisture than the original sample. These results indicated that the effective solids loading (bone-dry) of a CWF would be lowered by over $2 \%$ (such as from $70 \%$ to $68 \%$ ) by these two factors and that a CWF of $66-68 \%$ solids loading could be produced, which was later demonstrated (Table $X X)$.

This difference in behavior of the two coals raised serious questions as to the influence of beneficiation upon slurriability. To answer these questions, several investigations were undertaken by others addressing

(a) changes in mineral matter during beneficiation,

(b) changes in surface properties as a result of beneficiation, and

(c) confirmation and relevance of the equilibrium moisture and oxidation findings. 
TABLE XX

ANALYSIS OF LOWER KITTANNING CWF

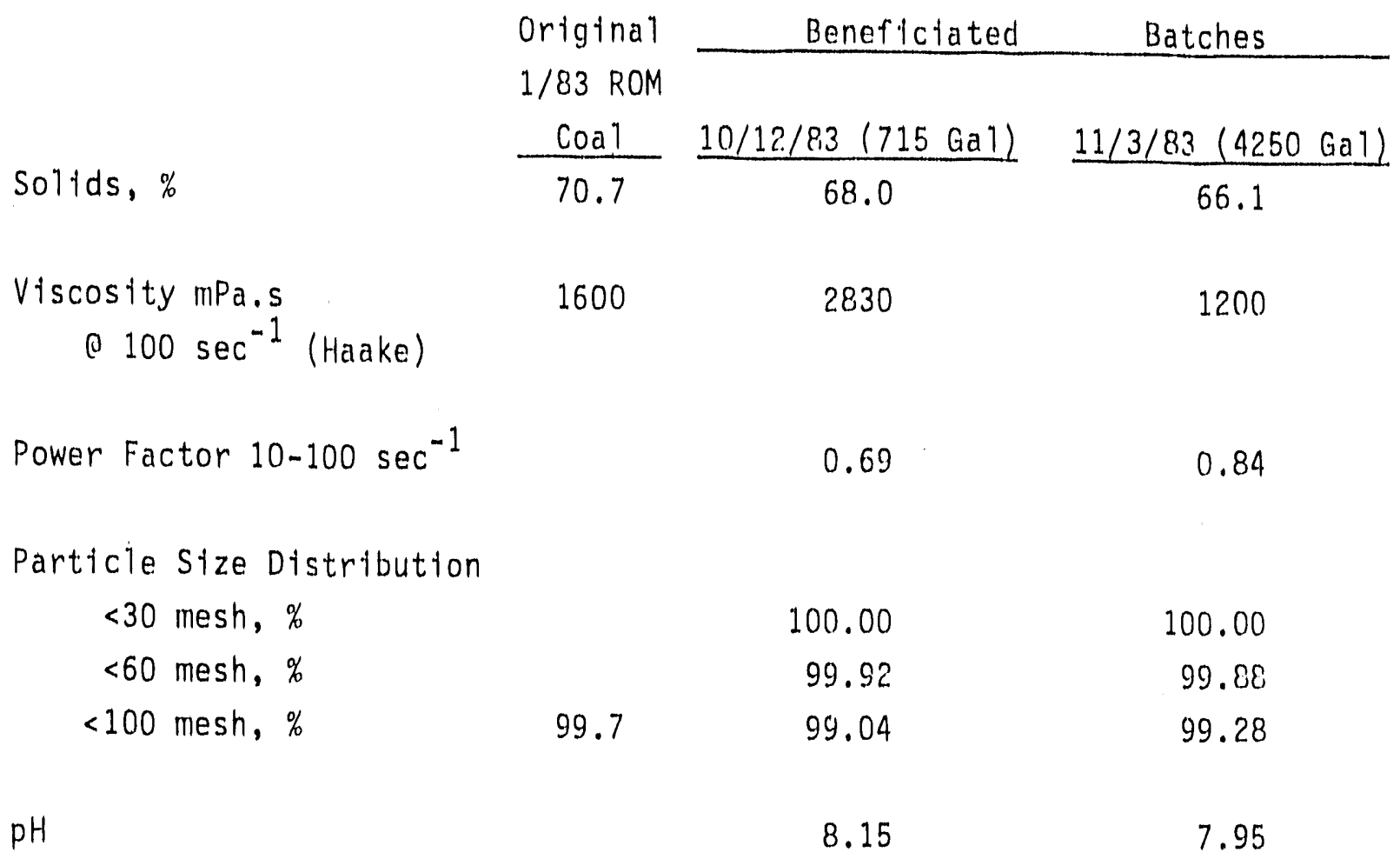


Based on the information developed, it was concluded that the reason the beneflclated Lower Klttarining coal would not consistently produce a $70 \%$ solids CWF with acceptable viscosity is assoclated with a volumetric property or maximum packing fraction. It appears that the polar groups on the surface of the highly oxidized coal immobllize through hydrogen bonding a sufflcient quantity of water to significantly increase the effective volume and decrease the maximum packing fraction so that an acceptable $70 \%$ solids CWF could not be produced. The highly oxidized condition resulted from the inadvertent inclusion of some outcrop coal in the coal supply.

The next coal evaluated as feed for the reference slurry was the Splash Dam. Four hundred tons of coal beneficlated to approximately $6 \%$ ash were purchased and representative quantities furnished to the vendors for production of small batches of CWF. Properties are summarized in Table XXI.

These data demonstrated that several manufacturers could produce acceptable CWF from the Splash Dam coal, and it was chosen as the reference coal.

Representative data for the Splash Dam CWFs are shown in Tables XXII and XXIII. In genera1, densities ranged from 1.203 to 1.211 , the $\mathrm{pH}$ varted from 7.7 to 9.6 , the mean volume of the minus 200 mesh coal ranged from 14 microns to 24.5 microns, the viscosity decreased with increasing temperature, higher temperature increased the rate of settling but did not induce hard pack, freeze-thaw cycles caused some separation but essentially original properties were restored with gentle mixing, some particle agglomeration occurred, and five gallon sample stabllity was indicative of large-scale storage behavior. Data on other CWFs are given in Volumes 3,4 , and 5 .

In order to preserve the anonymity of CWF manufacturers, an alphabetic code letter for each was used. To each CWF made for this program, an identification label which provides an abbreviated description of the CWF was assigned. For example, SD64C refers to a CWF for which the source coal is Splash Dam, the ash level is $6.4 \%$, and the manufacturer is company $C$. Source coals are abbreviated as follows: $U F=$ Upper Freeport, $S D=S p l a s h$ Dam, $C G=$ Cedar Grove, $L K=$ Lower Kittanning, and $A L=A 1 m a$ Seam. 
TABLE XXI

PROPERTIES OF SMALL BATCHES OF CWF PRODUCED FROM SPLASH DAM COAL BENEFICIATED TO $6 \%$ ASH

\begin{tabular}{|c|c|c|c|c|c|c|}
\hline \multirow[b]{4}{*}{ Vendor } & \multirow{4}{*}{$\begin{array}{c}\text { Soltds } \\
\text { Content } \\
\% \\
\end{array}$} & \multicolumn{2}{|c|}{ Viscostty } & \multirow{2}{*}{\multicolumn{2}{|c|}{ Particle Size }} & \\
\hline & & \multirow{3}{*}{$\begin{array}{l}\text { MPa.s } 0, \\
100 \mathrm{sec}^{-1}\end{array}$} & \multirow{3}{*}{$\begin{array}{l}\text { Power Law } \\
\text { Factor 10-100 } \\
\text { sec }^{-1}\end{array}$} & & & \\
\hline & & & & \multicolumn{2}{|c|}{$\%$ of CWF } & \\
\hline & & & & +30 Mesh & -200 Mesh & Stabllity \\
\hline$A$ & 68.9 & 1405 & 1.4 & 0.001 & 95.6 & Softpack \\
\hline C & 71.2 & 1010 & 1.3 & 0.003 & 95.2 & Softpack \\
\hline$E$ & 67.9 & 1209 & 0.98 & 0.004 & 99.6 & Softpack \\
\hline
\end{tabular}


TABLE XXII

PROPERTIES OF LARGE BATCHES OF SPLASH DAM CWF

\begin{tabular}{|c|c|c|c|c|}
\hline Manufacturers & $A$ & C & $D$ & $E$ \\
\hline Soldds Content $(\%)$ & 68.9 & 70.1 & 70.7 & 66.4 \\
\hline Particles $+30 \operatorname{Mesh}(\%)$ & 0.001 & 0.001 & 0.001 & 0.015 \\
\hline Particles -200 Mesh (\%) & 87.8 & 94.7 & 96.7 & 99.6 \\
\hline Inttial Sediment & Soft & Soft & Soft & Soft \\
\hline After Stirring & Dispersed & Dispersed & Dispersed & Dispersed \\
\hline Denstly @ $25^{\circ} \mathrm{C}$ & 1.203 & 1.211 & 1.204 & 1.205 \\
\hline $\mathrm{pH}$ & 9.6 & 8.8 & 7.9 & 7.7 \\
\hline \multicolumn{5}{|c|}{ Viscosity $0100 \mathrm{sec}^{-1}$ (mPa.s): } \\
\hline $\begin{array}{l}20^{\circ} \mathrm{C} \\
30^{\circ} \mathrm{C} \\
40^{\circ} \mathrm{C}\end{array}$ & & $\begin{array}{l}635 \\
463 \\
341\end{array}$ & $\begin{array}{l}837 \\
436 \\
370\end{array}$ & $\begin{array}{l}858 \\
608 \\
554\end{array}$ \\
\hline
\end{tabular}

Power Low Exponent between 10 and $100 \mathrm{sec}^{-1}$ :

$\begin{array}{lllll}20^{\circ} \mathrm{C} & 1.0 & 1.4 & 1.5 & 1.2 \\ 30^{\circ} \mathrm{C} & 0.9 & 1.3 & 1.1 & 1.0 \\ 40^{\circ} \mathrm{C} & 0.9 & 1.2 & 1.1 & 1.3\end{array}$


TABLE XXIII

STABILITY SETTLING COLUMN DATA

VENDOR C SPLASH DAM CWF

Temperature $20^{\circ} \mathrm{C}$

Positton, $\%$ solids

$\begin{array}{ccccc}\text { Day } & 1 & 2 & 3 & \text { Bottom } \\ \text { Feed } & 70.1 & 70.1 & 70.1 & 70.1 \\ 1 & 70.3 & 70.2 & 70.4 & 70.5 \\ 2 & 70.1 & 69.8 & 70.0 & 70.3 \\ 3 & 69.8 & 69.6 & 69.5 & 70.5 \\ 9 & 70.4 & 69.9 & 70.4 & 71.6 \\ 16 & 70.5 & 70.1 & 70.1 & 70.9\end{array}$

Temperature $40^{\circ} \mathrm{C}$

$\begin{array}{ccccc}\text { Feed } & 70.1 & 70.1 & 70.1 & 70.1 \\ 1 & 69.6 & 69.6 & 69.8 & 70.6 \\ 2 & 70.2 & 70.1 & 70.1 & 69.1 \\ 3 & 70.0 & 70.1 & 68.8 & 70.4 \\ 9 & 69.5 & 69.7 & 70.1 & 71.6 \\ 16 & 69.6 & 70.0 & 69.9 & 73.7\end{array}$

Temperature $60^{\circ} \mathrm{C}$

7

67.7

71.8

73.3

*1-Liter Plastic Contatner - Heated, Frozen, Sectioned, Analyzed 


\section{CWF PREPARATION AND SUPPLY}

The purpose of this activity was to provide representative samples of CWFs required for the test program. Activities consisted of coordination and supply of the appropriate fuels, in the required quantities and, in the proper time frames. The work was divided into four parts:

1. Coal Acquisition - This activity included the acquisition and beneficiation of parent coals in the quantities required for evaluations and tests, which include that required for the 18 candidate CWFs selected for bench-scale testing, the coal required for the 5 CWFs tested during the combustion evaluation, and the coal required for the 12 CWFs evaluated during the performance testing.

2. Beneficiation of Test Coals - The clean coals for preparing the CWFs for the large-scale combustion tests were produced from the beneficiation of the selected raw coals at coal cleaning plants.

3. CWF Preparation - Clean coals were shipped to the selected slurry manufacturers who prepared CWF in the required quantities for the tests.

4. CWF Supply - Representative test samples of each CWF were shipped to appropriate testing facilities for laboratory analysis or combustion testing as required during execution of the project.

Batches of CWF were procured from five CWF vendors, who used feed coals obtained by Gulf Research and Development Company (GRDC). The coordination of scheduling, shipping and storing was also done by GRDC, to match the test schedules.

Four coals were obtained to produce eighteen small batches of CWF for bench-scale screening tests. Three out of these four coals were used to produce large batches of CWF for the commercial-scale combustion tests under 
Task 4. A berieficiated microfine coal was obtained in addition to the four coals to produce twelve CWFs for the pllot-scale slagging and fouling evaiuation under Task 5.

Most coals were washed by the coal companies, while several batches were beneficiated by CWF vendors or Iowa State University. Three coals were shipped directly to $C-E$ for baseline dry pulverized coal tests. Figures 14 , 15 and 16 illustrate the histories of the Splash Dam, Cedar Grove, and Upper Freeport coals used in the project. The Alma coal used for microfine CWF production was shipped directly from the mine/cleaning plant to the CWF manufacturer to $C-E$. 


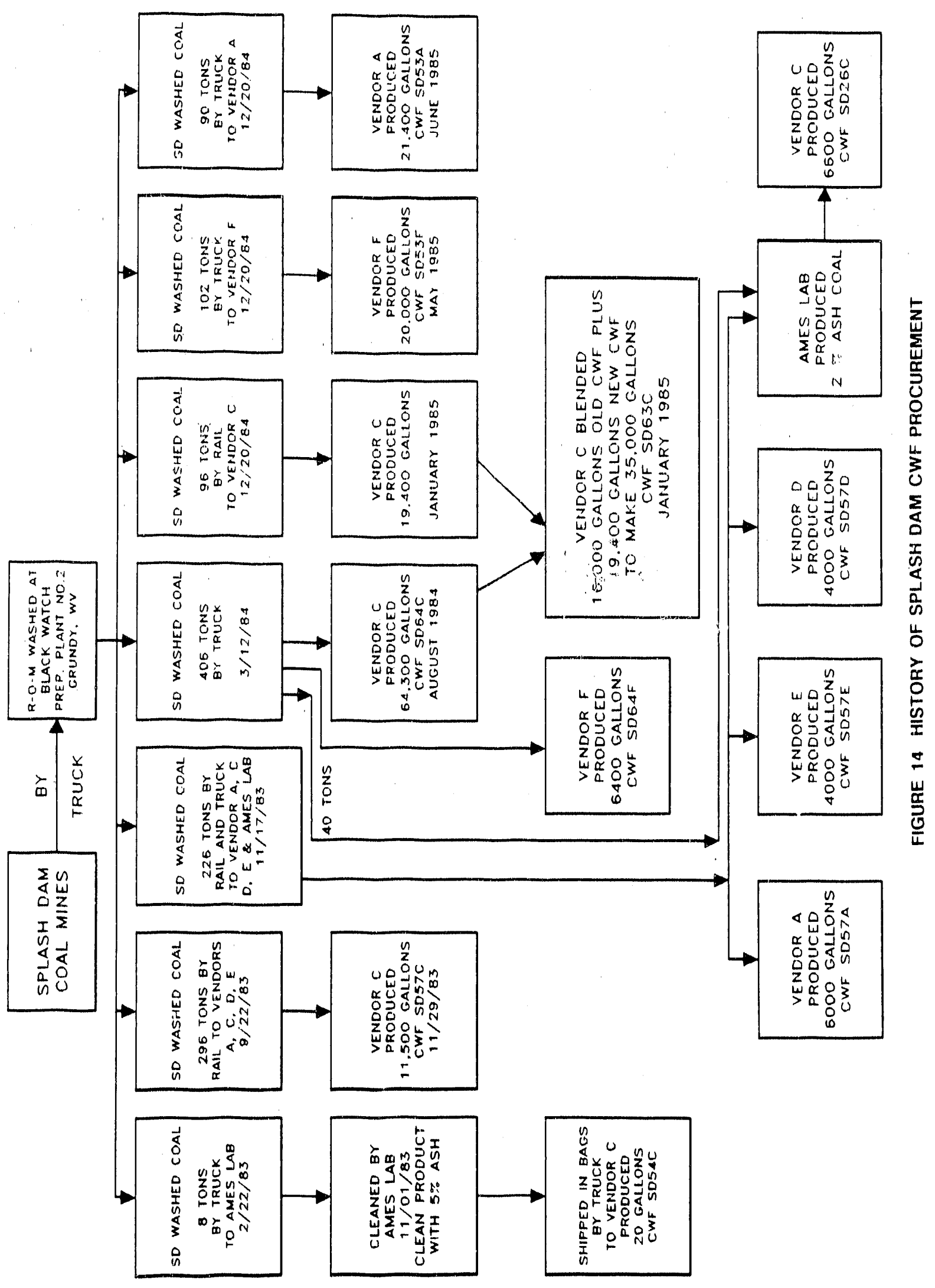




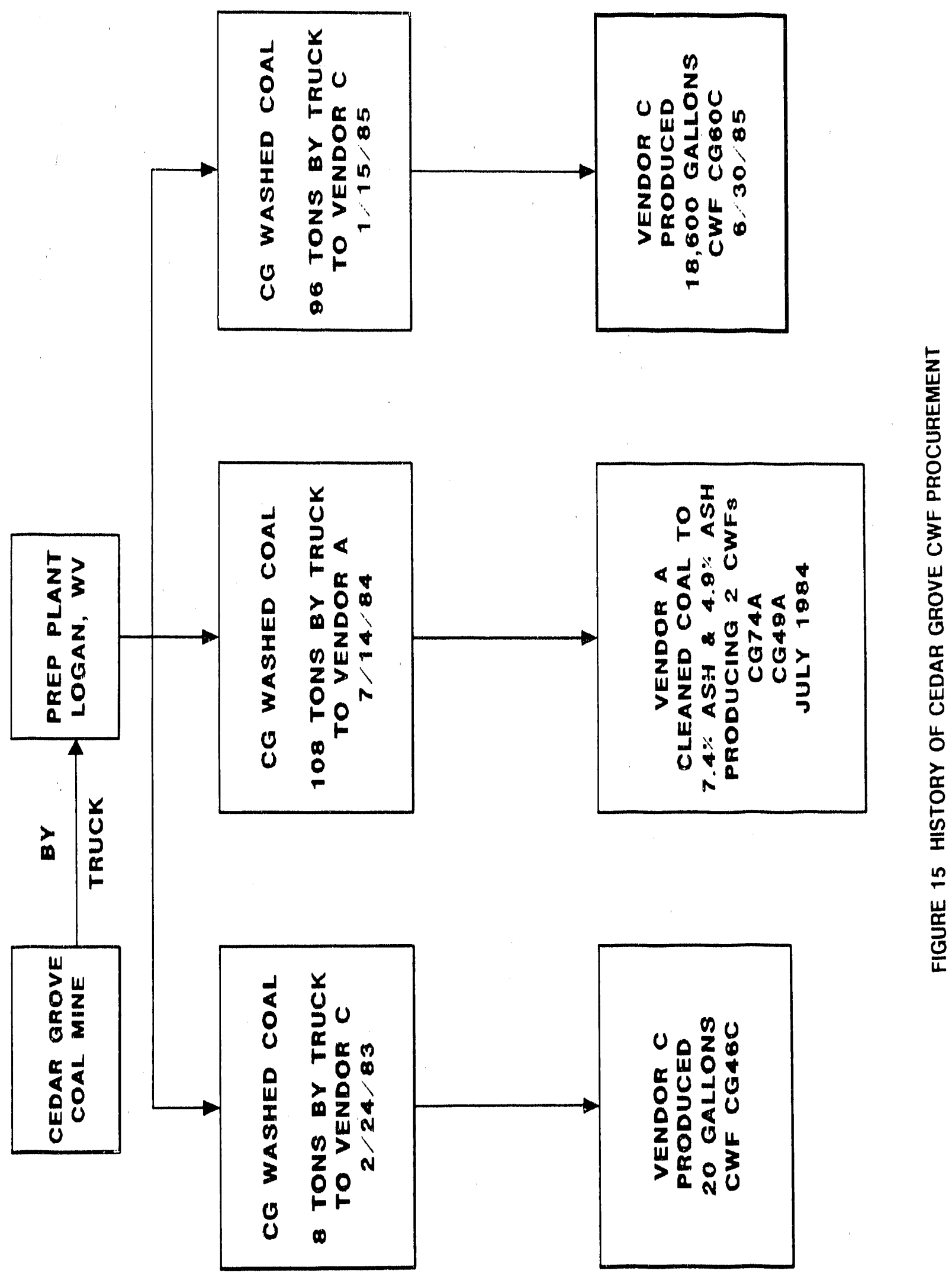




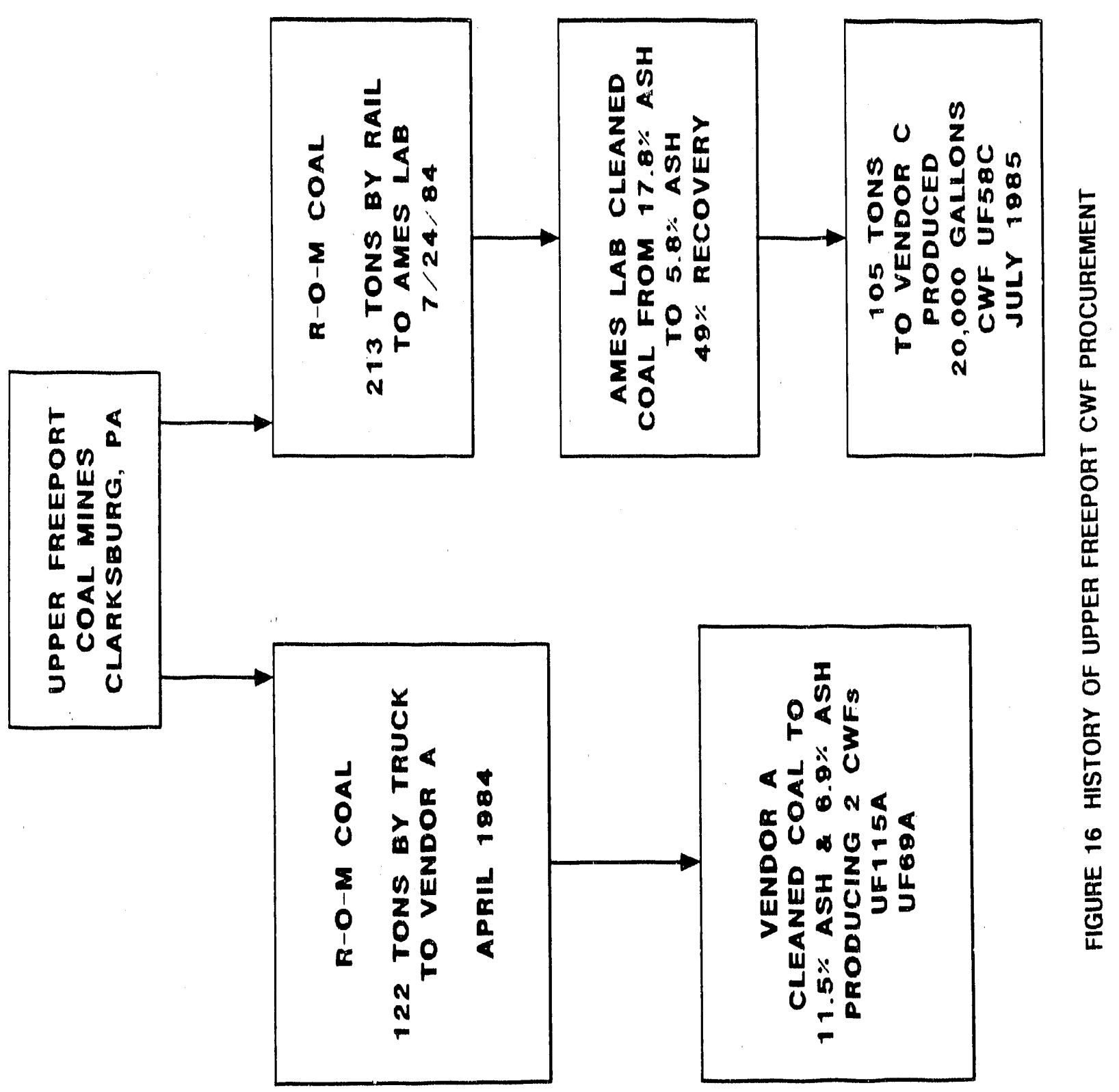




\section{CWF TRANSPORTATION TEST}

Gulf Research \& Development Company designed and assembled a data acquisition system which recorded the following conditions during transportation of two CWFs over 2700 miles: outdoor ambient temperature, CWF temperatures at five levels, vibration in the vertical plane, and pressure in the tank.

The data acquisition system was battery-powered and required no attention during transit. Except for some components, the data acquisition system was housed in two weatherproof and tamperproof cabinets. This system was affixed to a 1500-gallon tank which was mounted on a flatbed truck trailer. Data were collected and stored continuously during transit. Then, at the desitination the data were "dumped" via telephone line to a personal computer at GR.DC in Harmarville, PA.

A portable, skid-mounted, 1500-gallon tank, 48-inch diameter by 16 feet, with horizontal profile was hauled on a flatbed trailer. CWF was loaded through a manway in the top and drained through a bottom nozzle. Samples were obtained through the manway. Instrumentation had been inserted upward through a 3 inch port on the bottom surface of the tank. Data acquisition components were thermocouples, accelerometer, pressure transmitters, vibration meter, data logger, tape recorder, and telephone modem. The monitoring system is depicted in Figure 17.

The "heart" of the data acquisition system was a sma11, portable data logger which collected all measurements. It logged data continuously during transit, integrated data each hour (per each $\log$ cycle), then stored the integrated data in its random access memory (RAM) and on a cassette tape for backup.

In the laboratory, a static test was performed in order to compare settling at constant temperature and no vibration with that settling which may have occurred during transportation. An elongated steel drum was constructed to simulate the depth (48 inch or $120 \mathrm{~cm}$ ) of CWF in the 1500-gallon tank. Samples were taken through a port in the center of the lid. Data were collected during two shipments of coal-water fuel in September and october 1989. 


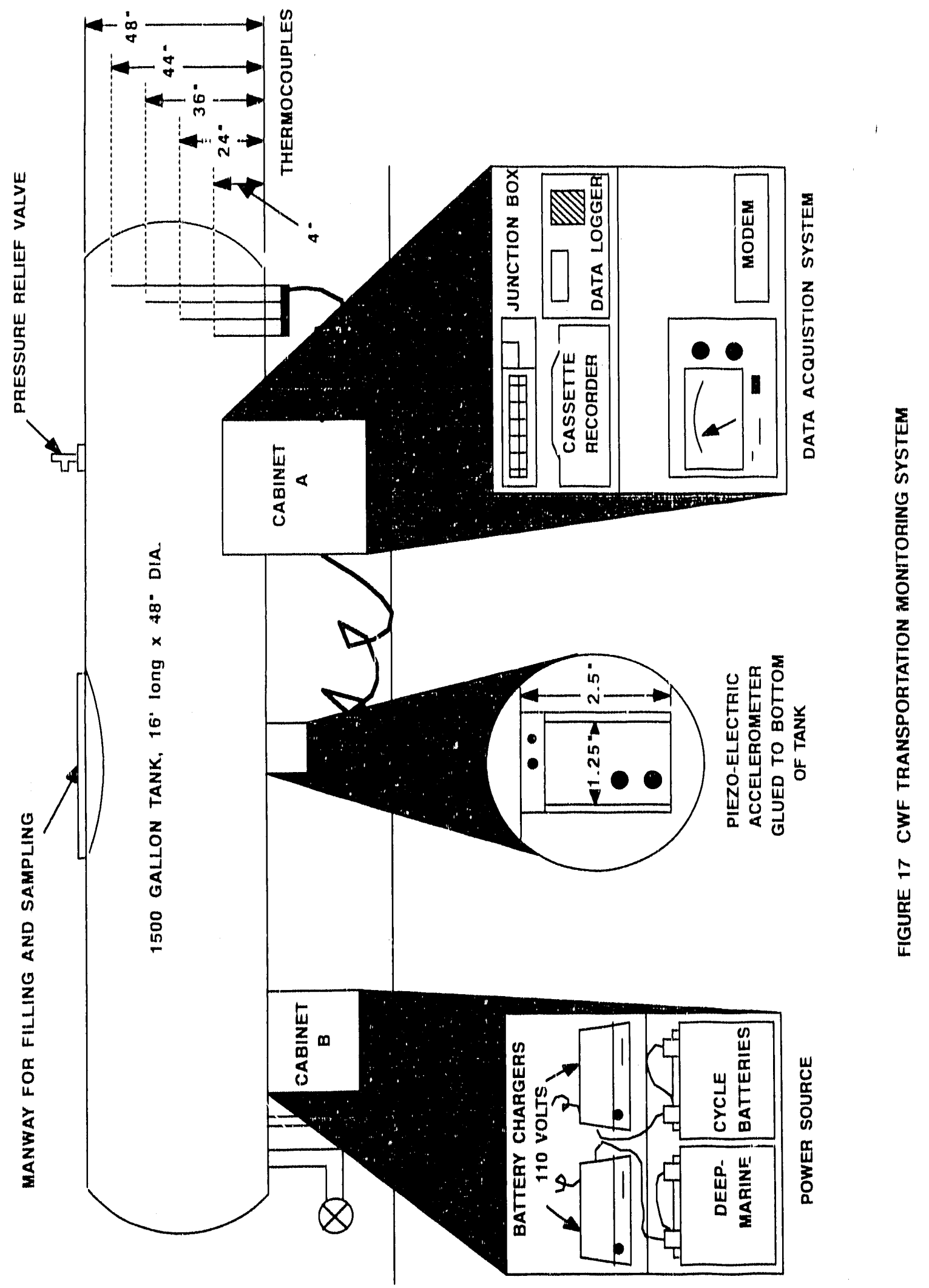


Monitoring of Transportation Conditions

A coal-water fuel containing $2.2 \%$ ash, made from Splash Dam coal by Vendor C, was shipped to TRW in September 20-25, 1984. For the fitst time transportation conditions were monitored during the nearly 2700-mile trip. Measurements included:

- outdoor ambient temperature

- internal temperatures at two levels within the CWF

- vibration of the tankful of CWF

- tark pressure

Data from the above-mentioned measurements are presented in Figures 18, 19, and 20. A11 graphs were plotted using hourly integrated data; i,e, data were collected every minute then averaged for an hourly point.

Due to corrosion, only 2 of 5 internal thermocouples functioned. Corrosion on three wire leads caused opened circuits and, therefore, no temperature readings were recorded.

As expected, the CWF did not experience the extremes of ambient temperatures, which ranged from $14^{\circ} \mathrm{C}\left(57^{\circ} \mathrm{F}\right)$ to $34^{\circ} \mathrm{C}\left(93^{\circ} \mathrm{F}\right.$ ) (see Figure 18 ). Temperature in the mid-top of the CWF (36 inches from bottom of tank) varted over a narrower range than that near the tank surface (top and bottom, not side of tank). Temperature of CWF near the top surface (44 inches from bottom or 4 inches down from top) ranged from $16^{\circ} \mathrm{C}\left(61^{\circ} \mathrm{F}\right)$ to $37^{\circ} \mathrm{C}\left(98^{\circ} \mathrm{F}\right)$, while temperature near the center ranged from $26^{\circ} \mathrm{C}\left(77^{\circ} \mathrm{F}\right)$ to $34^{\circ} \mathrm{C}\left(93^{\circ} \mathrm{F}\right)$. These two temperatures over the 6 day period are plotted in Figure 19.

Vibration data for this first trip (Trip 1) are plotted in Figure 20 . These integrated values include both minor vibrations and large shocks. The zero values correlate with the times when the truck was not moving. Based on the experience of the GRDC personnel, a value above 2 units represents travel over rough highway while values below 2 units represents travel over smoother 


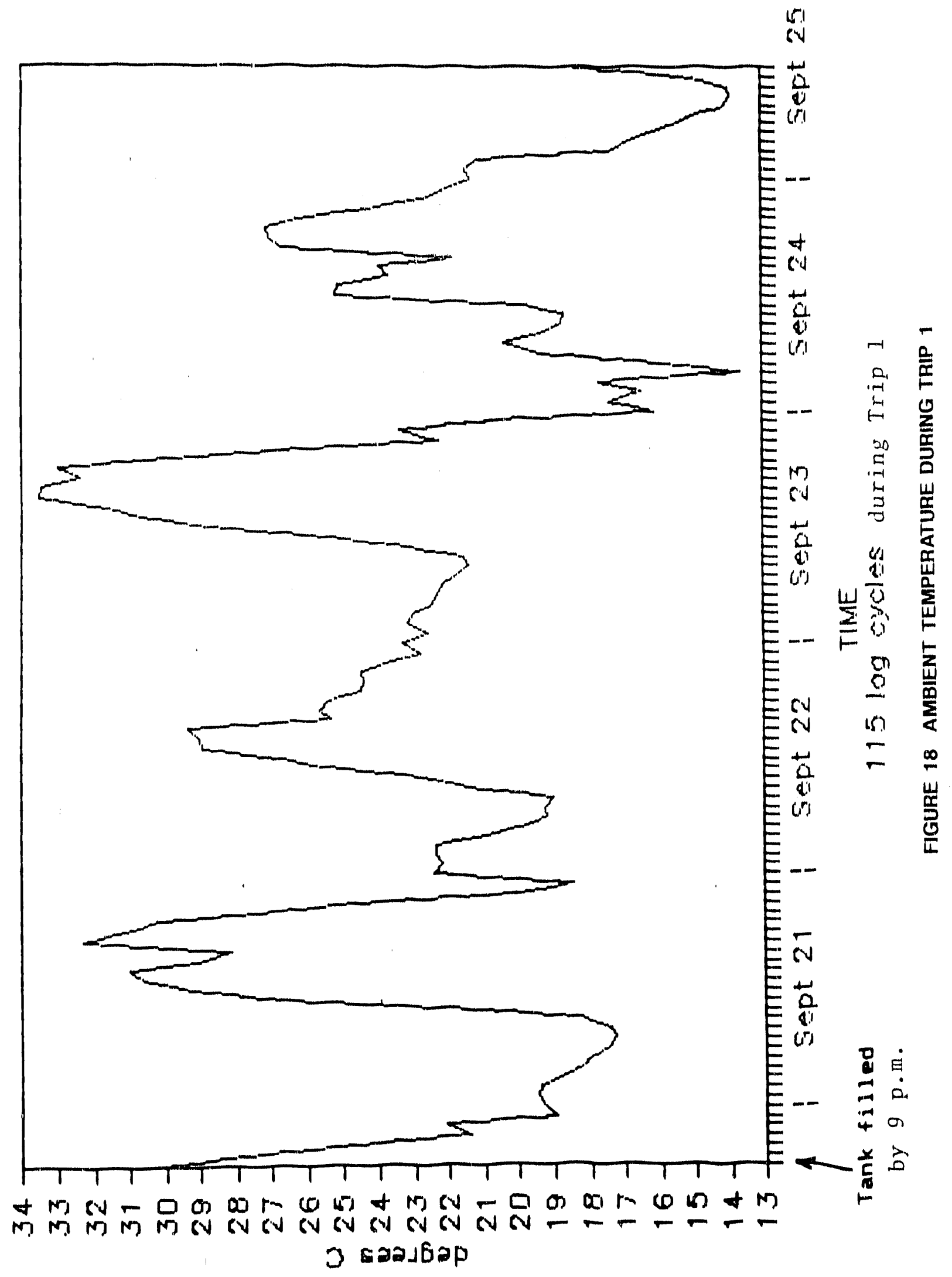




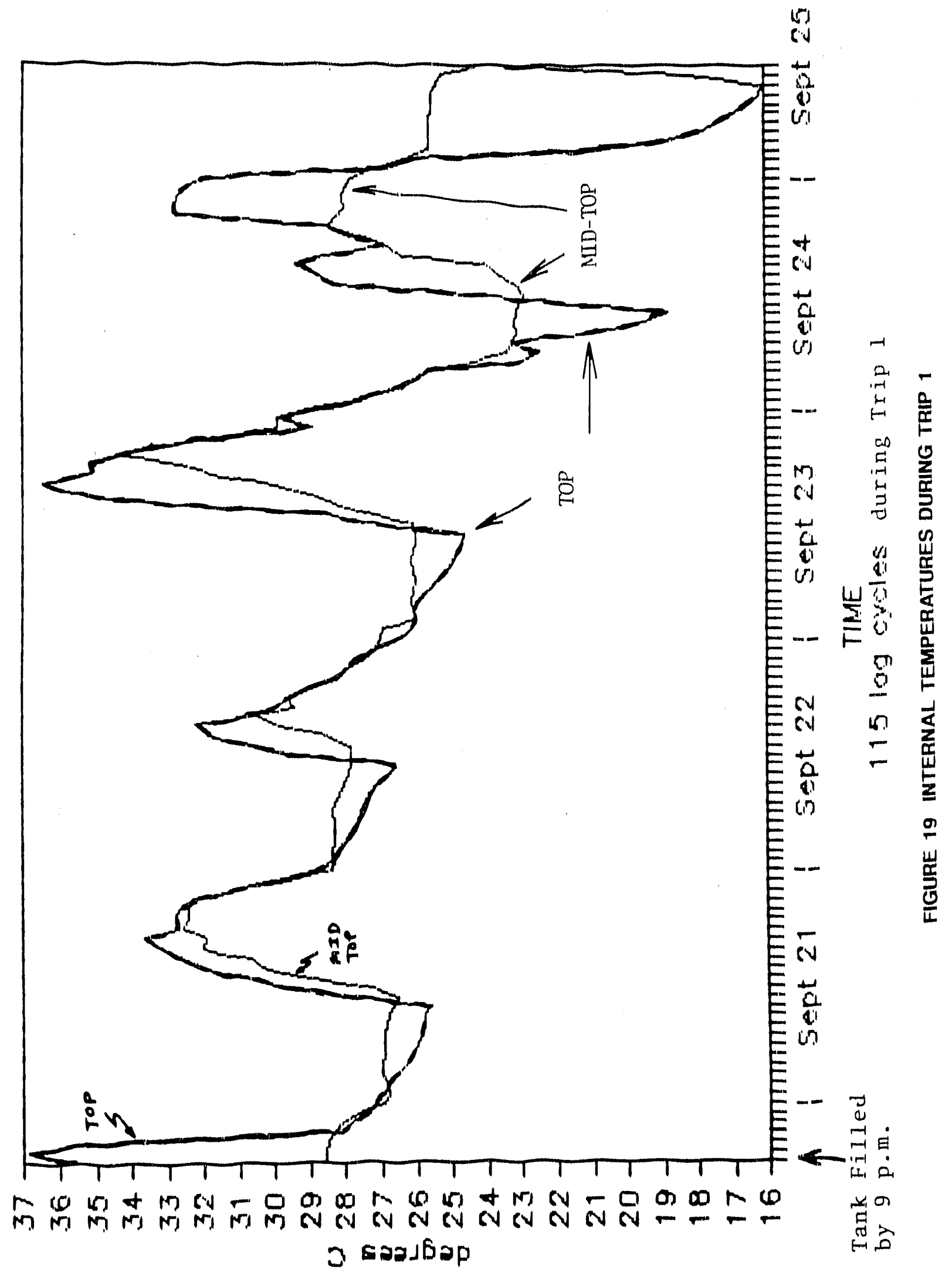




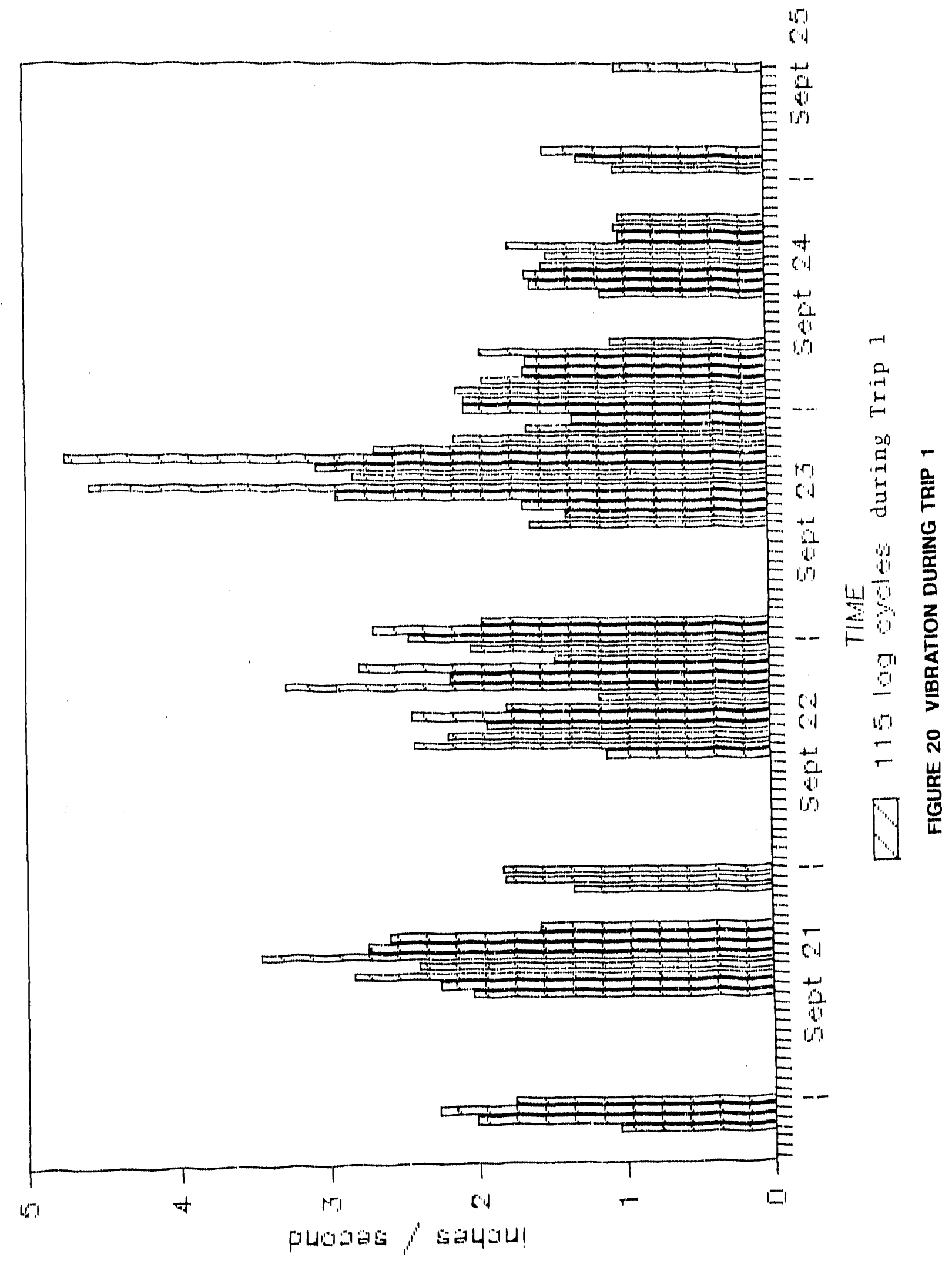


sections of highway. According to the manufacturer of the vibration detector/meter (Bruel \& KJaer), temperature fluctuations had no signiffcant effect on vibration measurement.

To place these measurements into perspective, a compartson was made with data from other dynamic Vtbration tests. Table XXIV w'as obtatned from an EPRI Report which reported on other vibration studies. By assuming vibration frequencies of $100-200 \mathrm{~Hz}$, the values in Figure 20 indicate that the vibrations experfenced during Trip 1 were in the range of truck travel over unimproved roads.

The internal tank pressure was measured at a point 8 inches below the surface. The tank pressure varied from a low of $1.8 \mathrm{psig}$ to maximum of $4.7 \mathrm{ps}$ ig correlating very well with the changes in anblent temperature.

A system based on differential pressure measurements was designed to infer settling as a result of density changes. Initially the measurement of rressures was planned at four different levels by use of one differential pressure cell and a rotating selector valve with connecting lines. Due to mechanical problems and time and money constraints, satisfactory instrumentation was not developed; however, the concept appears to be sound.

In October 1984, a second CWF (SD64F) was shipped from Vendor $F$ in the East to the TRW test site in Calffornla. Like the first trip, this shipment was continuously monitored for temperature and vibration. A GRDC technician traveled with the CWF and sampled tt periodically at four different levels for subsequent analysis of solids content. The settling data are reported in Table XXV.

Transportation of these two CWFs from the East Coast to California had no detectable effect upon their observed properties. Comparison of the stablitty data from static and transit samples showed that very little setting occurred. The settling behavior observed in the laboratory paralleled the behavior observed during transportation. 
Table XXIV

VIBRATION MEASURED IN FIFLD

\begin{tabular}{|c|c|c|c|c|}
\hline \multirow[b]{2}{*}{$\begin{array}{l}\text { Transportation } \\
\text { Mode } \\
\end{array}$} & \multirow[b]{2}{*}{$\begin{array}{l}\text { Frequency } \\
\text { Range }(\mathrm{Hz})^{*}\end{array}$} & Peak & \multicolumn{2}{|c|}{ Vibration Velocity } \\
\hline & & $\begin{array}{l}\text { Acceleration } \\
\text { Level (g's)* }\end{array}$ & at $100 \mathrm{~Hz}$ & at $200 \mathrm{~Hz}$ \\
\hline Ship & $0-20$ & $\begin{array}{l}0.4 \text { - average } \\
0.9 \text { - peak }\end{array}$ & - & - \\
\hline Ratl & $0-2.0$ & $\begin{array}{l}0.9 \text { - average } \\
2.0 \text { - peak }\end{array}$ & - & - \\
\hline $\begin{array}{l}\text { Truck on } \\
\text { highway }\end{array}$ & $0-100$ & $\begin{array}{l}0.5 \text { - average } \\
2.0 \text { - peak }\end{array}$ & 1.2 & - \\
\hline $\begin{array}{l}\text { Truck on } \\
\text { untmproved roads }\end{array}$ & $0-200$ & $\begin{array}{l}0.5 \text { - average } \\
3.0 \text { - peak }\end{array}$ & - & 0.9 \\
\hline $\begin{array}{l}\text { * "Coal-Water-Sll } \\
\text { Results", Elect } \\
\text { Final Report, }\end{array}$ & $\begin{array}{l}\text { ry Evaluatior } \\
\text { ic Power Res } \\
\text { bruary } 1984 .\end{array}$ & $\begin{array}{l}\text { Volume 2: Lab } \\
\text { ch Institute, }\end{array}$ & $\begin{array}{l}\text { ory and Co } \\
I-C S-3413,\end{array}$ & $\begin{array}{l}\text { on Test } \\
\text { ct 1895-3, }\end{array}$ \\
\hline
\end{tabular}


TABLE XXV

Transportation Sett1ing Test - Trip 2

(CWF in drum on 10/11/84, 70.5 wt\% solids)

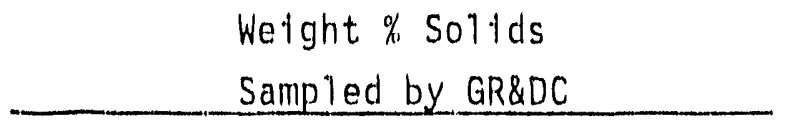

$10 / 12$

$10 / .13$

$10 / 14$

$10 / 16$

Date

Depth**

6.5 inches

19

33.5

41

$\begin{array}{ll}70.7 & 70.6 \\ 70.9 & 71.0 \\ 71.2 & 71.2 \\ 71.5 & 70.8\end{array}$

70.6

70.9

70.9

71.1

71.1

71.1

71.2

70.6

7

70.5

19

70.4

30

70.8

42

71.1

* TPW used their sampler; 70.9 weight \% solids after sparging.

** Depth from top surface of CWF. 


\section{CONCLUSIONS}

Five of the eight coals selected for detailed washability studies were capable of being cleaned to $2 \%$ ash. These source coals include the Cedar Grove, Lower Elkhorn, Black Creek, Splash Diam, and Lower Kittanning. General ratings of the coals relative to their washability, combustion, and suitability as CWF feeds are prosented in Table XXVI.

The CWF vendors expressed concern over the need to produce high-solids CWFs from all coals. The problem was twofold: a reliable slurriability criteria did not exist as part of the coal selection process; and production of CWFs with high solids loading level could create significant problems in control of rheological and stability characteristics of different CWF batches.

Esforts to identify any coals, other than the Splash Dam, that completely met the initial targets for this program, were unsucressful. Therefore, the following changes in the program were made:

1. Relaxation of the CWF solids loading requirement to 65 percent. This permitted evaluation of the Lower Kittanning Coal in CWF.

2. If the solids loading cannot be relaxed, then the washability requirements must be reevaluated. If two percent ash coals need no: be produced, the field of prospective coals is greatly enhanced.

Based upon experience to date, other conclusions can be made as to the state of CWF technology.

1. Development of specifications and test methods will entail collection of test data from a large number of CWFs. The $\therefore$, ts utilized in this program are useful, and vendors have developed their own quality control methods that are considered part of their technology. Many vendors will hold shipment if the CWF does not meet their private specifications. 


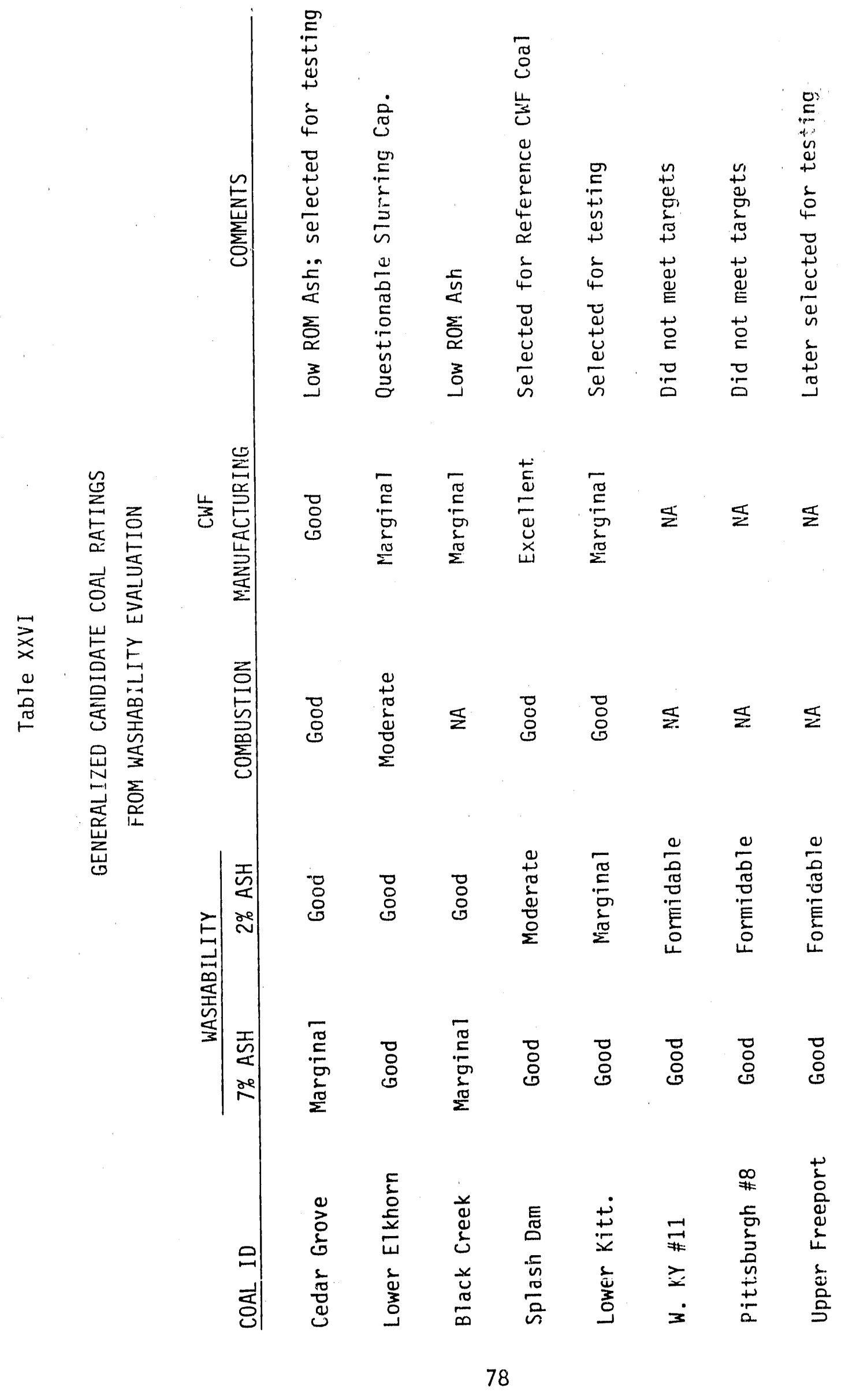


2. Vendors ordinarily perform development work prior to undertaking CWF production with a new coal, because formulations are somewhat coal specific. This is similar to what is found in the refining industry, where changes in crude $0 i 1$ make adjustments in operating conditions necessary.

3. In some cases, "specifications" should be regarded as "desired properties," the most important of which are viscosity and stability.

4. The bench-scale tests utilized in this program represent an initial contribution to the eventual ability to predict transportation, storage, pumping and combustion behavior of CWF.

5. Transportation of CWF by tiruck over long distances can be done with no deleterious effects.

6. A11 CWFs procured were of usable quality for the combustion tests.

Considering the fact that CWF fuels were relatively new, it was not too surprising that properties varied with coal selection. This has improved with further developments in the technology. 

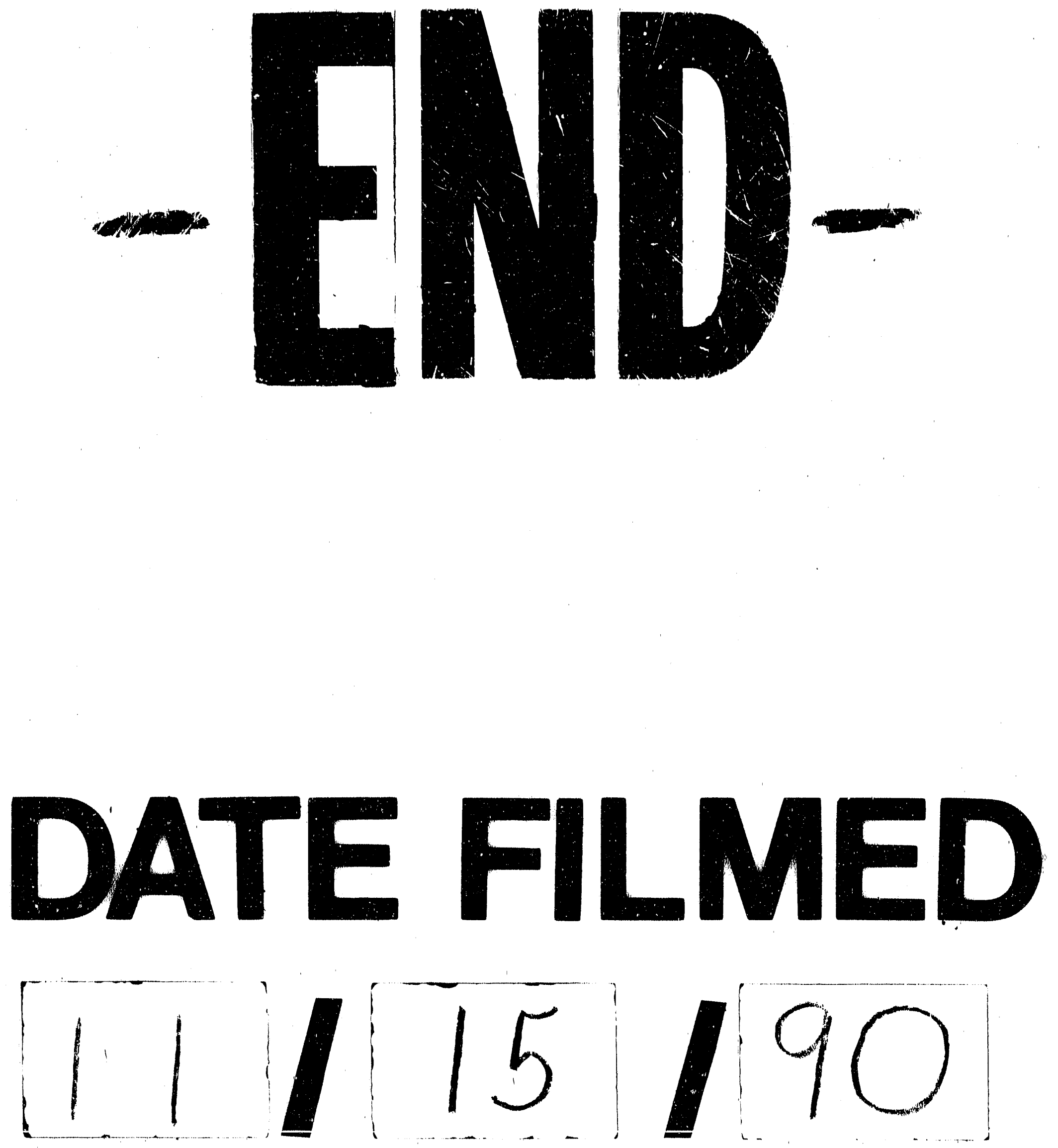
